\title{
Relative prices in
} Latin America in periods of low inflation and \section{structural change}

\author{
Pedro Sáinz and Sandra Manuelito
}

Pedro Sáinz

Former Director of the Statistics Division and the Economic Projections Centre, ECLAC

$\infty$ pedro.sainz@cepal.org<smiles>[R]</smiles>

lative prices and price stability have a recognized identity in economic theory and economic policy. In the last 50 years it is possible to configure numerous scenarios, according to the relative importance given by Latin American governments to price stability and relative prices. In the current debate, relative prices have been receiving less attention than price stability. Underlying this appears to be the belief that, with inflation low, the dispersion coefficient for variations in the prices of the goods and services included in the consumer price index should decline as well. The present article, in addition to describing the recent evolution of relative prices in a number of the region's countries, shows that this belief does not accord with the facts, identifies homogeneous groups of goods and services at either end of the distribution and raises some questions about the implications of this last finding.

Sandra Manuelito

Economic Affairs Officer,

Economic Development Division,

ECLAC

œ sandra.manuelito@cepal.org 


\section{I}

\section{Introduction}

The aims of sections I to IV of this article are, firstly, to show what a wide range of goods and services an examination of relative prices in an economy might encompass, and to point out that the present study includes just a part of this range, so that there is scope for taking it further in future. The second aim is to place the current situation as regards relative prices and price stability in Latin America in a broader historical context, to give an idea of how important the relationship between relative prices and economic stability, transformation and growth is now and will continue to be in future.

Inflation, as measured by the rate of increase in the consumer price index (CPI), and the structure and variation of relative prices, i.e., of the different goods and services making up the CPI basket, have been matters of interest for Latin American economic policymakers from the post-war period to the present day. Very briefly, the characteristics associated with the region in international comparative analyses during the 1950s and 1960s were high inflation and the use of relative prices as a policy instrument. Nonetheless, the variations of both the CPI and relative prices now occur in an economic environment far different from the situations prevailing in the region in the last 40 years of the twentieth century. By the early 2000s, the CPI was rising far more slowly -annual increases were in single digits in most of the countries. At the same time, the issue of relative prices had lost ground for a number of reasons, in particular an explicit or implicit belief that low levels of inflation were being matched by a fairly stable relative price structure; i.e., that the growth rates of different prices were subsiding fairly evenly, so that relative prices were changing little or, to put it another way, were displaying stable or diminishing relative dispersions. Of the sections indicated, IV covers the evolution of the consumer price index in Latin America between 1972/73 and 2003 and shows the scale of the changes observed.

Sections V and VI examine the cases of Chile and Brazil, opening the way to a detailed analysis of the behaviour of consumer price indices in the 1990s and early 2000 s at both the aggregate and individual component levels. This is done for product groups and individual products included in the basket used to compile the CPI, "products" being understood to mean both the goods and the services making up this index. The reason for choosing Brazil and Chile is that those two countries have managed to reduce their inflation rates significantly and have explicitly committed themselves to particular inflation goals. The conclusions drawn from the cases of these two countries will be developed to show the main regional tendencies of both CPIS and their components for a number of countries in the region. It will be demonstrated that, contrary to what is assumed by many analysts, the dispersion of price variations in the present context of low inflation is greater than in many periods of high inflation in the past.

Section VII describes the main factors that, in our opinion, largely account for the way goods and services price variations have developed in Latin America. Section VIII, lastly, presents the main conclusions of this study and some considerations concerning the importance of public policies in determining several of the goods and services prices included in the consumer price index. 


\section{II}

\section{Some conceptual considerations}

Although the decision was taken, for the reasons set out above, to focus the analysis on the evolution of the consumer price index and its components, it seems advisable to place this coverage in a broader framework, as we believe that this study and its results provide compelling reasons to take the analysis further.

The most commonly used concept of inflation is the rate of increase in the cost of a basket of goods and services representing private consumption, generally expressed by the consumer price index. This approach is not necessarily the most helpful for examining the progress of the economy, and economists have found it necessary to resort to broader measures of inflation. ${ }^{1}$

The main limitation of the CPI in terms of its ability to reflect inflation is its limited coverage of goods and services. It normally excludes certain durable consumer goods, capital goods, the value of financial assets and, above all, the value of fixed assets such as housing and land. By so doing, it fails to provide the measurements needed for one of the major areas of research in market economies, namely the relationship between price stability, monetary policy, economic cycles and financial asset prices. An additional (and related) consideration is that one of the greatest concerns for public policymakers is to prevent major crises caused by sharp falls in currencies and asset prices. Large swings in financial asset prices (financial bubbles and sharp stock market falls) occurring in combination with stable consumer price indices have been and remain a puzzle. Consequently, the CPI is not a sufficient instrument on its own for dealing with the issue of price stability or for describing the broad evolution of relative prices. Nor can other key economic issues, such as the relative prices of capital and labour, be analysed by recourse to the components of the CPI alone.

The influence of relative prices on resource allocation and personal welfare is another conceptual aspect of the greatest importance. In economic policy terms, government measures that influence the establishment of a relative price structure and its variations or stability over time are a crucial issue of permanent relevance. There are many areas for debate here. One is the legitimacy and advisability of government involvement in shaping a relative price

\footnotetext{
${ }^{1}$ See Laidler (2003) and Goodhart (2000).
}

structure. Some believe it is most desirable for prices to be set by the market; in the view of others, measures to regulate particular prices, guided by medium- and longterm technical or political criteria, can be an indispensable tool of economic transformation and growth, especially in countries that start out at a disadvantage to the most advanced economies. Arguments have been put forward in favour of the kind of public intervention used to assist the early stages of a late industrialization process, to balance the development of a country's regions, and to control markets that are oligopolistic or monopolistic either because of their nature or owing to the concentration of economic power. It is also justified as a mechanism for transferring resources to poor or intermediate social strata. Conversely, it is attacked for giving rise to a poor allocation of resources, or as an illegitimate mechanism for defending group interests. Naturally, the importance of these conceptual aspects will vary depending on whether it is a very high-inflation process that is being analysed or one in which inflation is low.

For the reasons given, and even though analyses which use the CPI are subject to the limitations described above at both the aggregate and individual component level, the reference point used in this study will be changes in the relative prices of the goods and services making up the CPI. ${ }^{2}$

\footnotetext{
${ }^{2}$ The results of this research have clearly shown that price dispersion in the aggregate does not have a direct relationship with inflation and that underlying both phenomena are explanatory variables associated with product group prices that have opposing dispersions and are determined by specific sectoral policies, and with other prices influenced by monetary policy. In the aggregate, the hypothesis that dispersion (as measured by the dispersion coefficient) falls with inflation is not borne out. Consequently, no attempt has been made here to establish an econometric relationship between the dispersion coefficient and inflation. In the bibliography, where this issue is covered, attention is drawn to the article by Vining and Elwertowski (1976) dealing with price indices in the United States. That article examines theoretical positions concerning the mutual dependence or independence of changes in the general price index and in the goods and services prices composing it. In particular, empirical tests are carried out for the United States economy to establish whether there is a relationship between the variances of the consumer and wholesale price indices and those of the individual product prices making up these indices, the conclusions being that they are not independent but are positively correlated. Cukierman (1983) reviews the subsequent discussion.
} 


\section{III}

\section{Relative prices and inflation in Latin America}

At the present time, price stability as measured by CPI variations is a subject of far greater interest to both the public and economic policymakers than relative prices. Nonetheless, governments are taking policy measures to regulate prices for a large group of goods and services. At the conceptual level, price regulation measures applied to substantial portions of the CPI basket will influence the evolution of the CPI, a fact that deserves to be made explicit. Before dealing with the issue in today's circumstances, we shall provide a brief historical review which, as well as showing that Latin America has always had relative price policies, will help to explain why interest in the two issues has shifted on several occasions over the last 50 years.

The economic transformation in Latin America during the 1950s, 1960s and 1970s was marked by widespread use of relative prices as a policy instrument in a number of areas. The priority was to set relative prices in such a way as to guarantee or facilitate investment or production in the industrialization or infrastructure sectors or programmes that governments had identified as being of prime importance. The origins of this price intervention can be traced to the prevailing mode of accumulation and to political pacts between social strata, and it gave rise to processes of growth and change in which crises occurred with some frequency. Management of these relative prices was bound up with administrative allocations, the accomplishment of development goals, and shortages, with their consequences for the purchasing power of the population, balance-of-payments and fiscal deficits and bouts of inflation, all of which played an important part in the economic history of Latin America in the past. ${ }^{3}$ That history also included high economic growth rates, which have not recurred, and far-reaching social and political change. ${ }^{4}$

These policies were attacked for causing inflation and distorting the structure of domestic prices as compared with those of international trade or the price structures of developed countries, and these criticisms underlay many of the proposals for change in the development approach. The proposals called for

\footnotetext{
${ }^{3}$ See Pinto (1968).

${ }^{4}$ See eClac (1985).
}

drastically reduced government intervention in the setting of relative prices, including balanced fiscal accounts and an end to subsidies. They also called for a relative price structure oriented by international trade prices, in the case of tradable goods, and by the free play of market forces or by regulation based on market return criteria, in the case of non-tradable goods and services.

The shift from the earlier development approach to today's was complex, as was the evolution of relative prices and inflation, but it is not the intention of the present paper to describe or study this. ${ }^{5}$ The crisis of the 1980s brought a second period of change. The agreements reached with the International Monetary Fund (IMF) called for efforts to bring the trade balance of the balance of payments into surplus, as a mechanism for servicing the external debt or at least some of the interest payments. National currencies devalued sharply and there were severe economic recessions. These phenomena resulted in very high inflation which, in combination with constraints on domestic demand, once again altered relative prices, acutely so in many countries. The shift in prices was so marked that in some countries economic recovery was due in part to a rise in domestic production that brought idle capacity back on stream or replaced imports in the late 1970s. One example of this is the case of Chile in the 19831990 period, which shows how important relative prices can become in the evolution of an economy. ${ }^{6}$

At the same time, the high inflation rates suffered by some countries in the late 1980s and early 1990s (in excess of $1,000 \%$ a year in Argentina, Brazil, Nicaragua and Peru) placed producers and many

\footnotetext{
${ }^{5}$ Nonetheless, it is worth listing some of the characteristics of this shift. The period of external borrowing in the 1970s released governments from the balance-of-payments constraints of earlier decades, lifted national currencies against the dollar, allowed tariffs to be cut and, in many countries, thereby lowered the relative prices of consumer goods, particularly durables. A gradual reduction in fiscal intervention in many countries freed up prices for certain agricultural products and somewhat increased the prices of basic services. Currency appreciation brought down inflation rates. This was the first shift in relative prices and inflation.

${ }^{6}$ See Sáinz and Calcagno (1992).
} 
sections of society in a very difficult position. As inflation intensified, governments implemented antiinflation policies that in some cases had high social costs. From being treated as an instrument or outcome, the inflation rate became a target. These anti-inflation policies led to further shifts in relative prices, particularly in countries that used the exchange rate as an anchor in order to achieve a relatively rapid fall in inflation. Another method was to cut budget deficits, which meant reviewing price regulation policies in areas as sensitive as electricity, gas and water, agricultural products, fuels and transport. Privatization was also a factor in price changes for these goods and services.

This brief account of developments in inflation and relative prices shows that from the 1950s until well into the 1990s the region experienced powerful inflationary processes, including surges that took inflation rates to extremely high levels, and that the relative price structure underwent numerous changes and was only broadly stable in the post-war period and for brief intervals thereafter. It would be very difficult to account for economic developments in the region's countries without taking the inflation and relative price situation into account. To lose sight of the relative price picture would be to ignore a factor of fundamental importance in explaining the productive transformation and the distribution of welfare.

The very high inflation rates of the early 1990s, and increasing external liberalization in most of the countries, altered the relative importance of inflation and relative prices. Privatization and speculative capital inflows created a balance-of-payments cushion. Anti-inflation policies had more leeway, and the new openness to foreign trade gradually brought prices in tradable sectors more into line with those of international markets. $^{7}$

Conceptually, the defenders of low inflation attributed increasing importance to the role of low inflation in the countries' economic growth and development. They argued that this and a very low fiscal deficit (or none) were a necessary or even, in the view of some, a sufficient condition for development to take off. There was one area, however, where the use of anti-inflation instruments met with considerable obstacles. Privatization policies introduced to reduce

\footnotetext{
${ }^{7}$ Frenkel (1995) analyses the anti-inflation policies applied in a number of Latin American countries in the early years of the 1990s.
}

fiscal deficits led to price rises for some important services, including electricity, water and fuels, and the obvious effects of these on the welfare of different economic strata created higher levels of resistance.

In the late 1990s and 2000s, inflation had to be dealt with in new circumstances. In 1998 the external situation began to worsen, and efforts to reduce inflation and balance-of-payments deficits played a central role in government policy responses. This approach was partly imposed by the International Monetary Fund (IMF) agreements ${ }^{8}$ with the countries, partly dictated by the desire of governments to reap political capital from low inflation. It is now generally accepted in Latin America that a low inflation rate is a very important objective for the economic authorities. ${ }^{9}$ There is also a new institutional setting in which inflation targeting by independent central banks plays a significant role. ${ }^{10}$ Its emergence in the context of IMF adjustment policies adds to its importance. ${ }^{11}$ Nonetheless, there is still debate about its conceptual definition and the advisability of making it a central priority. ${ }^{12}$ It was also in this period that the consumer price index became increasingly important as an indicator, first, of domestic price movements in the economy, and second, of the stability of these prices.

In these circumstances, the subject of relative prices became less important. Two more or less implicit assumptions seem to have prevailed. The first was that low inflation was the outcome of a general reduction in the growth rates of the different groups of prices making up the index, or that fiscal austerity and liberalization policies bore down evenly on the different components; the second was that if there were different tendencies in the evolution of relative prices for the different groups of goods, these were stable and relatively small, and balanced each other without major deviations. As was said earlier, this article will seek to ascertain how the prices of the different goods and services in the CPI basket have behaved in a context of slower growth in the aggregate indicator.

\footnotetext{
${ }^{8}$ See Boughton (2004).

${ }^{9}$ See Barro (1995) for a treatment of a larger number of countries.

${ }^{10}$ See Fisher (1996). Bernanke, Laubach and others (1999) provide a detailed analysis of the scope of inflation targeting policies, case studies and the results obtained.

${ }^{11}$ Blejer, Leone and others (2002) analyse the use of inflation targeting programmes in the context of adjustment programmes applied at the behest of the IMF.

12 On this last point, and for the case of Brazil, see IPEA (2005, p. 51).
} 


\section{IV}

\section{The evolution of the consumer price index in Latin America}

Reference has been made to the large decline in inflation rates in the Latin American countries in the 1990 s and early 2000s. Some figures will now briefly be given to convey the level of price stability that has been achieved, with reference to the earlier situation of high inflation that characterized Latin America. In 1990, cumulative annual inflation to December as measured by the CPI was a little under $1,200 \%$, but in 2003 the cumulative annual rate of inflation in the same period was just $8.5 \%$, and in 2001 inflation touched a low of $6.1 \%$. As figure 1 shows, the inflation rate plunged in 1995 and has since remained at extremely low levels by Latin American standards. Thus, the high-inflation periods occurred mainly in the 1980s and early 1990s.

This result masks differences between the situations of the region's countries, however, and is strongly influenced by developments in Brazilian inflation rates (table 1). This is only to be expected, given Brazil's importance in the total once the overall result is weighted by population size in the different countries. ${ }^{13}$ Again, the high-inflation countries were not the same in the different periods: thus, in the 1970s the countries were Argentina, Chile and Uruguay; in the 1980s, the countries with the highest inflation rates were Argentina, Bolivia, Brazil, Nicaragua, Peru and Uruguay (it was in 1989 and 1990 that inflation peaked in many of the Latin American countries); and in the 1990 s, inflation fell considerably in the great majority of the region's countries, and in all cases was below $100 \%$. Although a number of countries experienced inflationary episodes, albeit with lower rates than in earlier years, the regional inflation rate remained at historically low levels.

${ }^{13}$ Brazil accounts for about $35 \%$ of the region's total population.

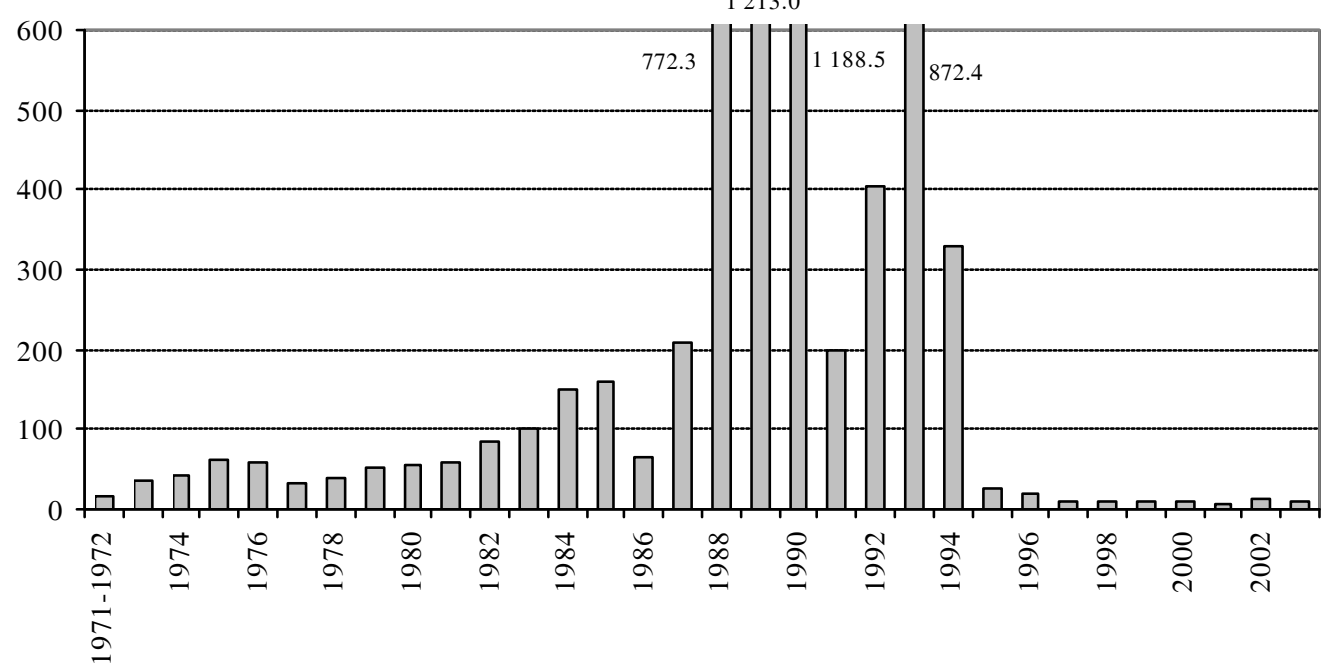

Source: Prepared by the authors based on official statistics. 
TABLE 1

Latin America and the Caribbean: Annual inflation rate,

December to December, selected years

(Percentages)

\begin{tabular}{|c|c|c|c|c|c|c|c|c|}
\hline & 1971-1972 & 1975 & 1980 & 1985 & 1990 & 1995 & 2000 & 2003 \\
\hline $\begin{array}{l}\text { Latin America and } \\
\text { the Caribbean }\end{array}$ & 17.3 & 60.9 & 56.1 & 159.4 & 1188.5 & 26.0 & 9.0 & 8.5 \\
\hline Argentina & 51.1 & 340.3 & 87.6 & 385.4 & 1343.9 & 1.6 & -0.7 & 3.7 \\
\hline Barbados & 10.2 & 12.3 & 16.1 & 2.4 & 3.4 & 2.8 & 3.8 & 2.2 \\
\hline Bolivia & 13.0 & 6.0 & 23.9 & 8170.5 & 18.0 & 12.6 & 3.4 & 3.9 \\
\hline Brazil & 16.0 & 29.4 & 95.3 & 239.1 & 1585.2 & 22.4 & 6.0 & 9.3 \\
\hline Chile & 79.3 & 340.7 & 31.2 & 26.4 & 27.3 & 8.2 & 4.5 & 1.1 \\
\hline Colombia & 15.2 & 15.3 & 26.5 & 21.8 & 32.4 & 19.5 & 8.8 & 6.5 \\
\hline Costa Rica & 4.0 & 21.5 & 17.8 & 10.9 & 27.3 & 22.6 & 10.2 & 9.9 \\
\hline Ecuador & 6.8 & 13.2 & 14.5 & 24.4 & 49.5 & 22.8 & 91.0 & 6.1 \\
\hline El Salvador & 2.3 & 15.1 & 18.6 & 31.9 & 19.3 & 11.4 & 4.3 & 2.6 \\
\hline Guatemala & 0.7 & 13.0 & 9.1 & 27.9 & 59.6 & 8.6 & 5.1 & 5.9 \\
\hline Haiti & 10.3 & 17.8 & 15.6 & 17.4 & 26.1 & 24.8 & 19.0 & 41.5 \\
\hline Honduras & 4.1 & 5.9 & 11.5 & 4.2 & 36.4 & 26.8 & 10.1 & 6.8 \\
\hline Jamaica & 0.0 & 14.7 & 28.6 & 23.3 & 29.8 & 25.6 & 6.1 & 14.1 \\
\hline Mexico & 2.2 & 16.0 & 29.8 & 63.7 & 29.9 & 52.0 & 9.0 & 4.0 \\
\hline Nicaragua & 0.0 & 0.0 & 24.8 & 334.3 & 13490.2 & 11.1 & 9.9 & 6.6 \\
\hline Panama & 3.9 & 1.8 & 14.4 & 0.4 & 0.8 & 0.8 & 0.7 & 1.5 \\
\hline Paraguay & 7.9 & 8.6 & 8.9 & 23.1 & 44.0 & 10.5 & 8.6 & 9.3 \\
\hline Peru & 6.0 & 25.5 & 59.7 & 158.3 & 7646.8 & 10.2 & 3.7 & 2.5 \\
\hline Dominican Republic & 9.3 & 16.5 & 4.6 & 30.9 & 79.9 & 9.2 & 9.0 & 42.7 \\
\hline Trinidad and Tobago & 6.5 & 13.4 & 16.6 & 6.5 & 9.5 & 3.8 & 5.6 & 3.0 \\
\hline Uruguay & 62.5 & 66.8 & 42.8 & 83.2 & 128.9 & 35.4 & 5.1 & 10.2 \\
\hline Venezuela (Bolivarian Rep. of) & 3.2 & 8.0 & 19.6 & 7.3 & 36.5 & 56.6 & 13.4 & 27.1 \\
\hline
\end{tabular}

Source: Prepared by the authors based on official statistics.

\section{V \\ The consumer price index and goods and services prices: developments in Chile and Brazil}

The detailed analysis of relative price developments during the 1990s and early 2000s was conducted by examining the cases of Brazil and Chile. Periods of high and low inflation were compared in both countries, and the distributions of the price variations for the different products were calculated by choosing periods in which each country used the same methodology and basket of goods to calculate the CPI. Then the most detailed product breakdown available was used to calculate the average rate of monthly variation in the price of each product, using the price index for the last and first month of the period. This yielded a distribution of average monthly rates of variation in the available product prices for the periods studied in each country. These distributions could then be used to calculate a set of distribution parameters, which were then examined in an attempt to answer the following questions:

(i) Did the characteristics of the distribution change when inflation fell? What were the most significant changes?

(ii) Did the dispersion coefficients of the distributions rise or fall when inflation fell?

(iii) Can products situated in different sections (quartiles, deciles) of the distribution be grouped using the most common categories employed to classify them (to one digit) in the CPI structure? 
The first two questions can be referred back to those raised in earlier studies dealing with the forms of the distribution and also to the debate that arose among the majority of analysts who saw a direct relationship between lower inflation and a reduction in relative price dispersion. ${ }^{14} \mathrm{We}$ did not find any applied economics studies for Latin America that might help us answer the third question, which is perhaps the most interesting of all given the effect that a stable trend in homogeneous groups might have on the allocation of resources and welfare.

The decision was made to study the evolution of the Brazilian and Chilean consumer price indices (at both the whole index and individual component level) for two reasons: first, the availability of statistical information, and second, the fact that these countries had succeeded in bringing inflation down substantially. Furthermore, as has already been pointed out, these are countries which have committed themselves explicitly in recent years to low inflation rates and price stabilization. The inflation developments in Chile and Brazil that are presented here basically occurred in the 1990s and early 2000s. Both countries had detailed information available on the evolution of prices for all products in the CPI basket. Two periods were studied for Chile: April 1989 to December 1998, and January 1999 to August 2004; in the case of Brazil, three periods were considered: July 1989 to December 1990, January 1991 to July 1999, and August 1999 to August 2004. In each case, the same methodology and product basket were used to measure prices in the different periods. In the case of Brazil, the second period was divided into two subperiods (January 1991 to June 1994, and July 1994 to July 1999) in order to bring out some major differences in the price evolution of the various products due to significant shifts in macroeconomic conditions. ${ }^{15}$

\footnotetext{
${ }^{14}$ Roger (2000) reviews the literature analysing the distributions of variation rates (or "relative prices", as they are called in those articles) in relation to the form of distribution of relative prices, understood as the rate of price variation in a given period.

${ }^{15}$ In the case of Chile, the CPI for the April 1989 to December 1998 period has April $1989=100$ as its basis; for the January 1999 to August 2004 period, the basis is December $1998=$ 100. In the case of Brazil, the bases for the different periods are as follows: for July 1989 to December 1990, the basis is June $1989=100$; for January 1991 to July 1999, the basis is December $1990=100$; for August 1999 to August 2004, the basis is July $1999=100$. For Brazil, the extended national consumer price index (Indice Nacional de Preços ao Consumidor Amplo (IPCA)) was used; the authors are aware of the scope of
}

Once the distribution was known, parameters could be calculated for it, including the average, the standard deviation, the dispersion coefficient and the characteristics of the quartiles and deciles for the different periods. The calculation procedure was as follows: first, as explained earlier, the average monthly variation rates for the different products included in the CPI were calculated using official figures from the countries (yielding a vector of variation rates $z$ ). ${ }^{16}$ Second, an average monthly rate was calculated for all these products. To this end, an unweighted arithmetical mean index of all products was calculated for the starting and ending months, and this was then used to estimate the average monthly variation of all the products; the same exercise was carried out for the official CPI. Third, the statistical parameters mentioned earlier were calculated. These calculations are presented mathematically in the appendix. In addition, the evolution ${ }^{17}$ of the official CPI in the different periods was compared with the evolution of the price indices for the different products. The same exercise was carried out at the product group level (one-digit classification), thus allowing the results to be compared. ${ }^{18}$ For simplicity's sake, we shall henceforth use the term "variation rates" for the average monthly rates of variation in the prices of the different components of the CPI basket in each of the periods.

this index and its differences from the national consumer price index (Indice Nacional de Preços ao Consumidor (INPC)), which has wider coverage, but the decision was taken to work with the IPCA because this is the reference indicator used by the authorities. In any event, when the authors used the INPC to conduct the same analysis as in the present study, for the last period considered, the conclusions about the behaviour of the price variation rates distribution were similar. The two subperiods for Brazil were chosen to reflect the timing of the Real Plan (on this subject, see Sáinz and Calcagno, 1999).

${ }^{16}$ In studies that analyse how rates of price increase are distributed, these rates are usually called "relative prices" (the price at time ${ }_{t}$ relative to the price at time ${ }_{t-1}$ ).

${ }^{17}$ The average monthly variation rate of the consumer price index in the period was compared with the average monthly variation rates of all goods and services.

${ }^{18}$ Indicators of kurtosis and skewness were also calculated for the two periods considered (kurtosis corresponds to the fourth moment of the distribution and skewness to the third). In the case of Chile, the distribution of the variation rates for the prices of the different goods and services shows greater kurtosis in the 1999-2004 period (5.3) than in the 1989-1998 period $(-0.13)$. The skewness indicators behave similarly in the first period (-0.19) and the second period (-1.19). 


\section{Chile}

To begin with, we shall examine the case of Chile (tables 2, 3 and 4). A first look at this set of indicators allows us to conclude that inflation decreased gradually and, with minor fluctuations, reached very low average levels in the 2000s. The unweighted average of $z$, meanwhile, also moved downward, indeed falling by more than the official CPI inflation rate. Dispersion, as measured by the dispersion coefficient, increased in the lower-inflation period, rising as inflation fell. In turn, price changes meant that in both

TABLE 2

Chile: Growth rate of the consumer price index and the prices of its components. Statistical indicators

\begin{tabular}{|c|c|c|c|c|c|c|c|c|}
\hline \multicolumn{4}{|c|}{ Full breakdown of the CPI components } & \multicolumn{5}{|c|}{ One-digit breakdown of the CPI component groups } \\
\hline \multicolumn{2}{|c|}{ Subperiods } & $\begin{array}{c}\text { April } \\
\text { 1989- } \\
\text { December } \\
1998\end{array}$ & $\begin{array}{c}\text { January } \\
\text { 1999- } \\
\text { August } \\
2004\end{array}$ & \multicolumn{2}{|c|}{ Subperiods } & $\begin{array}{c}\text { December } \\
1978- \\
\text { March } \\
1989\end{array}$ & $\begin{array}{c}\text { April } \\
\text { 1989- } \\
\text { December } \\
1998\end{array}$ & $\begin{array}{c}\text { January } \\
\text { 1999- } \\
\text { August } \\
2004\end{array}$ \\
\hline CPI & $\begin{array}{l}\text { Average monthly } \\
\text { price growth rate } \\
\text { (average monthly } \\
\text { inflation in the } \\
\text { period) }\end{array}$ & 0.94 & 0.23 & CPI & $\begin{array}{l}\text { Average monthly } \\
\text { price growth rate } \\
\text { (average monthly } \\
\text { inflation in the } \\
\text { period) }\end{array}$ & 1.29 & 0.76 & 0.54 \\
\hline \multirow[t]{2}{*}{$\begin{array}{l}\text { Average monthly } \\
\text { price growth } \\
\text { rates of the } \\
\text { products } \\
\text { composing } \\
\text { the CPI }\end{array}$} & Unweighted average & 0.84 & 0.08 & $\begin{array}{l}\text { Average monthly } \\
\text { price growth } \\
\text { rates of the } \\
\text { groups } \\
\text { composing } \\
\text { the CPI basket }\end{array}$ & Unweighted average & 1.59 & 0.66 & 0,18 \\
\hline & $\begin{array}{l}\text { Standard deviation } \\
\text { Dispersion coefficient } \\
\text { Median } \\
\text { First quartile } \\
\text { Fourth quartile }\end{array}$ & $\begin{array}{l}0.41 \\
0.49 \\
0.86 \\
0.60 \\
1.11\end{array}$ & $\begin{array}{r}0.50 \\
5.99 \\
0.06 \\
-0.14 \\
0.27\end{array}$ & & $\begin{array}{l}\text { Standard deviation } \\
\text { Dispersion coefficient }\end{array}$ & $\begin{array}{l}0.16 \\
0.10\end{array}$ & $\begin{array}{l}0.34 \\
0.51\end{array}$ & $\begin{array}{l}0.34 \\
1.87\end{array}$ \\
\hline $\begin{array}{l}\text { Number of components } \\
\text { in the CPI basket }\end{array}$ & & 368 & 482 & \multicolumn{2}{|c|}{$\begin{array}{l}\text { Number of components } \\
\text { in the CPI basket }\end{array}$} & 4 & 5 & 8 \\
\hline
\end{tabular}

Source: Prepared by the authors based on figures published by the Chilean National Institute of Statistics (INE).

TABLE 3

Chile: Growth rate of the consumer price index and the prices of its components. Indicators of dispersion in growth rates

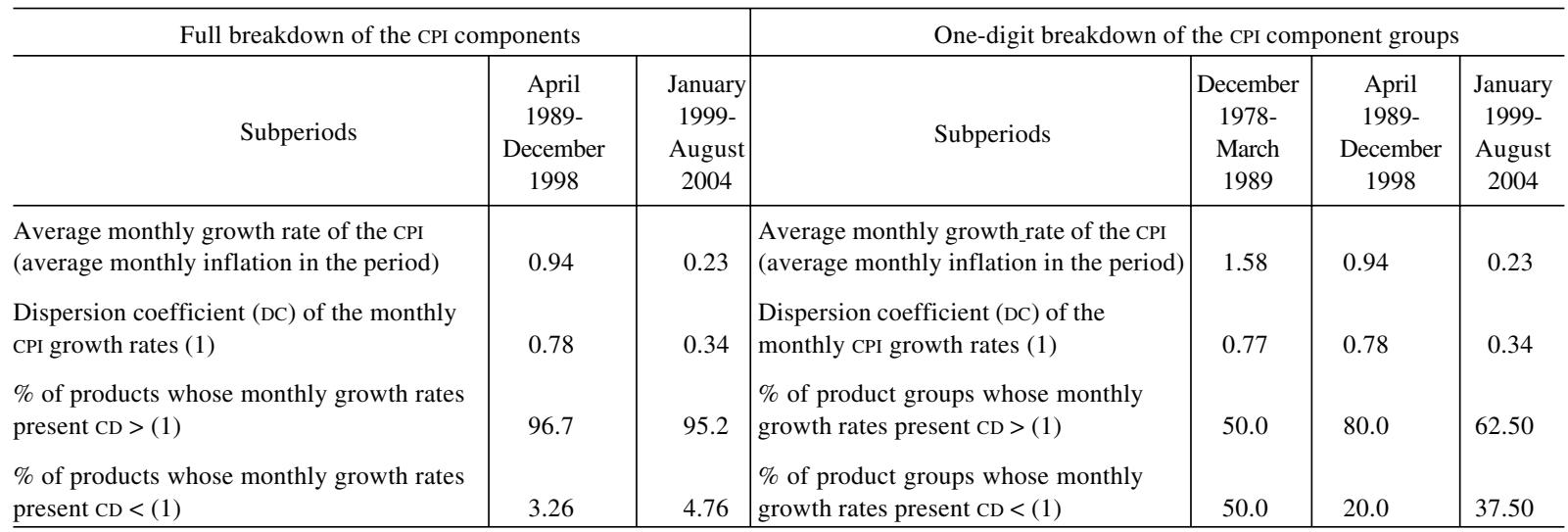

Source: Prepared by the authors based on figures published by the Chilean National Institute of Statistics (INE). 
Chile: Growth rate of the consumer price index and the prices of its components. Statistical indicators of distribution

(Cumulative rates in the period, as percentages)

\begin{tabular}{l|l|rr}
\hline \multicolumn{2}{c|}{ Subperiods } & $\begin{array}{r}\text { April 1989- } \\
\text { December 1998 }\end{array}$ & $\begin{array}{r}\text { January 1999- } \\
\text { August 2004 }\end{array}$ \\
\hline \multirow{2}{*}{ CPI } & Cumulative growth rates over the period & 194.9 & 16.6 \\
\hline Cumulative price growth & Highest value of the first quartile of the distribution & 100.1 & -9.1 \\
rates of the products & Lowest value of the fourth quartile of the distribution & 261.7 & 20.0 \\
composing the CPI & Highest value of the first decile of the distribution & 31.7 & -28.8 \\
& Lowest value of the tenth decile of the distribution & 369.2 & 34.5 \\
& Median & 171.4 & 4.3 \\
\hline
\end{tabular}

Source: Prepared by the authors based on figures published by the Chilean National Institute of Statistics (INE).

periods the average monthly CPI variation rate was greater than the unweighted average of the monthly average variation rates for the different products; this implies that a group of products whose prices rose by more than this average had a large weight in the CPI basket.

An analysis of the distribution of the variation rates included in $z$, in both periods, shows that this distribution presents different characteristics. In the first period studied, the median and the unweighted average are not much different, indicating that the distribution is fairly symmetrical. In the second period, however, the unweighted average is considerably lower than the CPI variation rate. ${ }^{19}$ It can be concluded, therefore, that in the second period analysed the goods and services prices that increased the most had a greater weight in the overall CPI calculation. If these products could not easily be substituted for by others whose prices increased by less, a reweighting at the end of the period could heighten the phenomenon. Furthermore, it transpires that the variation rates of the goods and services prices in the first quartile of the distribution were low enough to bring down the overall index, but at the same time their share of spending tended to fall, at least in certain social strata, owing to the difficulty of substituting for many of the goods and services in the upper part of the distribution.

In addition, although the distribution of $z$ in the second period (January 1999-August 2004) is more

\footnotetext{
${ }^{19}$ To take account of possible seasonal effects, a variation between January 1999 and January 2004 was calculated for the last period in Chile, and the results were similar. For example, the unweighted average of the variation rates was 0.085 and the dispersion coefficient was 6.4.
}

concentrated around the average, the outlying results are further from it. If a standardized analysis of the results is carried out, ${ }^{20}$ the change in the form of the distribution shows that the variations are concentrated around zero and that the "tails" (i.e., prices that vary in a significantly different way from those in this "core") ${ }^{21}$ are longer (figure 2). This can also be illustrated by the substantial decrease in the standard deviation of the variation rates composing the "core" between the two periods. It needs to be asked, then, whether price variations have really become more concentrated around this "core" or whether what we are seeing are not in fact more extreme variations in goods and services prices that fell or rose by more than in the earlier period. If the former is confirmed, the interpretation might be that the variation in a set of product prices formerly governed by an inertial effect became detached from the variation in other prices because de-indexation in the economy eliminated a tendency for prices in certain categories to adjust fairly automatically for inflation. At the same time, a smaller group of products that varied for non-inertial reasons now displays very high relative variations owing to the great stability around zero of the variations in the first set of products. In the second case, what would seem to be at work are more extreme price changes for goods and services whose variations have become detached from those of the group making up the "core",

\footnotetext{
${ }^{20}$ The variation rates included in the $z$ vector were standardized around the average in accordance with the following formula: $\left(X_{i}-X\right.$ average $) / s_{i}$, where $s_{i}$ is the standard deviation of the product ${ }_{i}$.

${ }^{21}$ By "core" is meant the second and third quartiles of the distribution, and by "tail" is meant the first and last deciles.
} 
FIGURE 2

Chile: Distribution of the average monthly price growth rates of the goods and services composing the CPI basket

(Standardized rates, as percentages)

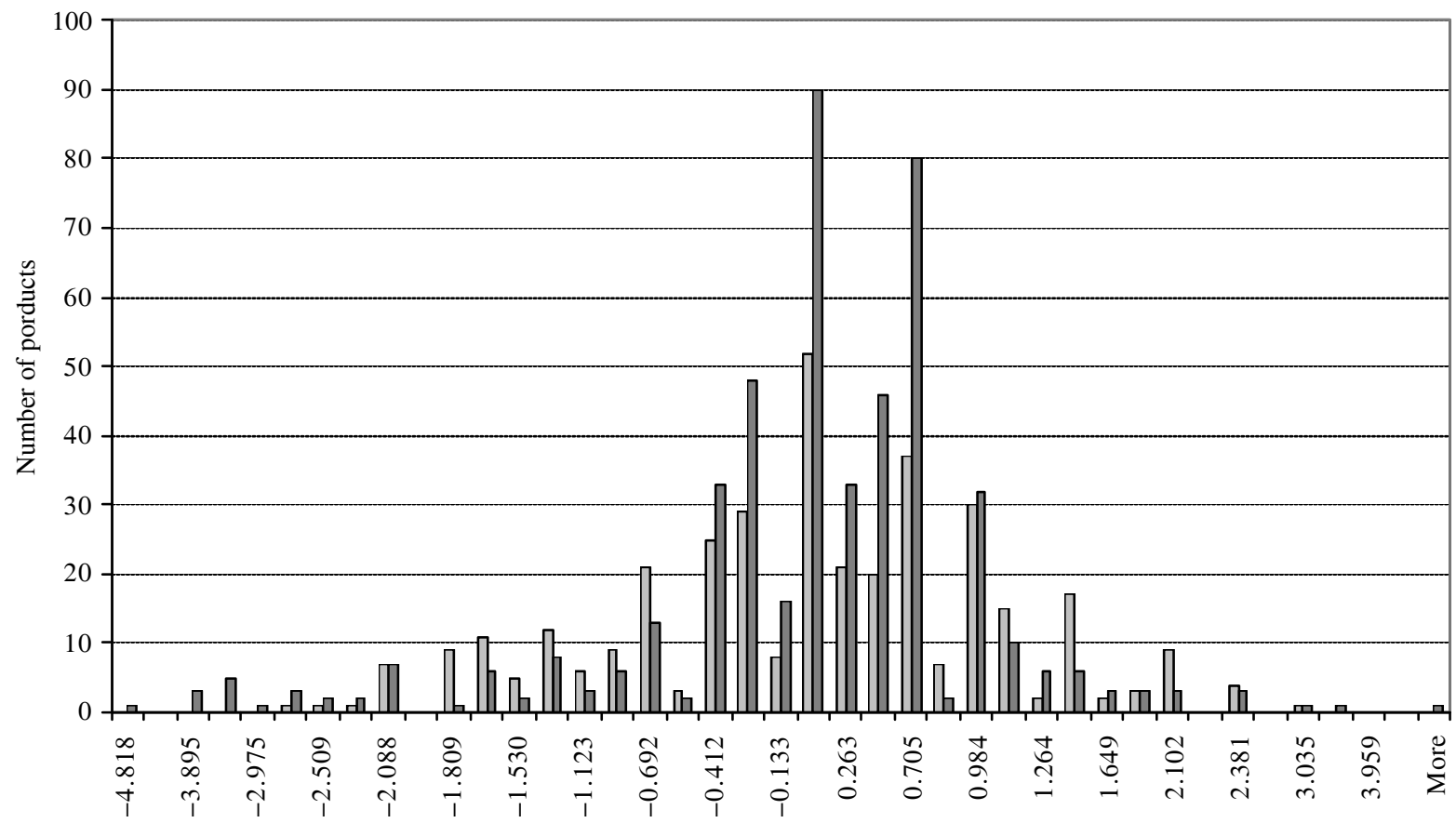

Standardized variation rates

$\square$ Apr 89-Dec $98 \quad \square$ Jan 99-Aug 04

Source: Prepared by the authors based on_figures published by the Chilean National Institute of Statistics (INE).

so that the supposed concentration of price variations in the core is really nothing but the effect of standardization with a considerably higher standard deviation. To elucidate the reasons for these changes, the distributions of $z$ in the two periods were examined with the first and last deciles removed. The result shows that the "core" has similar dispersions in both cases. The reason for the change in the distribution of variation rates can thus be found in the evolution of goods and services prices whose variation rates for this period are within these deciles.

One striking result is that the first decile of the $z$ distribution is now further from the average than the last decile. ${ }^{22}$ At the same time, concentration around the core is stronger to the right than to the left, ${ }^{23}$ which is consistent with the observation in the previous

\footnotetext{
${ }^{22}$ It can therefore be concluded that, in standardized terms, prices for these products fell by more than prices for products whose variation rates were in the last decile rose.

${ }^{23}$ There is also a rise in the skewness of the distribution of product price variation rates between the two periods studied,
}

paragraph. When this result is compared with the average monthly CPI variation rate in each of the periods, however, it can be seen that the effect of rising prices on the CPI variation is not offset by the reduction caused by falling prices. This is reflected in the fact that the CPI variation rate was $0.23 \%$ in the second period.

It now needs to be asked whether the variation rates of the prices in the different categories are grouped in the $z$ distribution in accordance with their product group classification (one-digit classification). The general answer is yes. It is also necessary to know how stable the positions of these concentrations are in the $z$ distributions of the two periods. To answer this question, the procedure described above ${ }^{24}$ was carried

even though the average for these variation rates is lower. Bryan and Cecchetti (1996) analyse the relationship between the average and the skewness of the variation rate distribution and conclude that this is not necessarily positive and could well be negative.

${ }^{24}$ The parameters of the relative price distribution were calculated year on year. 
out for each of the years in the different periods and the results were analysed to ascertain which categories were positioned in each of the deciles of the distributions obtained (table 5). The analysis also sought to ascertain whether the position of each of these categories was stable over the period (i.e., year on year) or whether their relative positions varied depending on the year. Further on, tables 6 and 7 present the dominant tendencies in the period as a whole. The main conclusions are that during the first period there was already a fairly stable degree of concentration for certain groups of categories, but others oscillated between one position and another. In the second period there was a stronger tendency for positions in the distribution to stabilize, especially in the first and last deciles.

As table 6 shows, in the first period considered there were some products (clothing, for example) whose prices consistently varied by less than the CPI, while the prices of other products such as health care usually rose more quickly than the index. Food prices, on the other hand, seem to have been more variable since their relative positions changed depending on the year. In the second period (table 7), fruit and vegetables, computer equipment, household electrical appliances, clothing and financial costs were in the first quartile, with averages that in some cases were negative in absolute terms. At the other extreme was, essentially, a group of services for which in some cases poorer consumers had no substitutes available, such as transport and transportation services, and basic services (electricity, gas and water).

We can conclude that the nature of the product groups situated in the first and last deciles is very different. Those in the first decile (i.e., those whose prices rise by least or even fall) are usually goods for which substitutes are available in the expenditure structure and whose prices are on a clear downward trend in international markets. Conversely, those in the last decile (those whose prices are increasing the

TABLE 5

Chile: Growth rates of the consumer price index and of the prices of the index components. Statistical indicators of distribution

\begin{tabular}{|c|c|c|c|c|c|}
\hline \multicolumn{6}{|c|}{ All goods and services in the CPI basket } \\
\hline Subperiods & & \multicolumn{2}{|c|}{ April 1989-December 1998} & \multicolumn{2}{|c|}{ January 1999-August 2004} \\
\hline CPI & Average monthly growth rate & 0.94 & & 0.23 & \\
\hline \multirow{8}{*}{$\begin{array}{l}\text { Average monthly } \\
\text { price growth rates } \\
\text { of the CPI } \\
\text { components }\end{array}$} & Unweighted average & 0.84 & 0.00 & 0.08 & 0.00 \\
\hline & Median & 0.86 & 0.07 & 0.06 & 0.11 \\
\hline & Highest value of the first & & & & \\
\hline & quartile of the distribution & 0.60 & -0.58 & -0.14 & -0.29 \\
\hline & Lowest value of the fourth & & & & \\
\hline & quartile of the distribution & 1.11 & 0.68 & 0.27 & 0.52 \\
\hline & Standard deviation & 0.41 & 1.00 & 0.50 & 1.00 \\
\hline & $\begin{array}{l}\text { Standard deviation (second } \\
\text { and third quartiles) }\end{array}$ & & 0.34 & & 0.23 \\
\hline
\end{tabular}

Excluding goods and services whose average monthly price growth rates are in the first and last deciles

\begin{tabular}{|c|c|c|c|c|c|}
\hline \multirow[t]{2}{*}{ Subperiods } & & \multicolumn{2}{|c|}{ April 1989-December 1998} & \multicolumn{2}{|c|}{ January 1999-August 2004} \\
\hline & & & $\begin{array}{c}\text { Standardized } \\
\text { data }\end{array}$ & & $\begin{array}{c}\text { Standardized } \\
\text { data }\end{array}$ \\
\hline \multirow{7}{*}{$\begin{array}{l}\text { Average monthly } \\
\text { price growth rates } \\
\text { of the products } \\
\text { composing the CPI }\end{array}$} & Unweighted average & 0.85109 & 0.00 & 0.05584 & 0.00 \\
\hline & Median & 0.87 & 0.06 & 0.06 & 0.03 \\
\hline & Highest value of the first quartile & & & & \\
\hline & of the distribution & 0.68 & -0.68 & -0.09 & -0.72 \\
\hline & of the distribution & 1.04 & 0.74 & 0.23 & 0.81 \\
\hline & Standard deviation & 0.26 & 1.00 & 0.21 & 1.00 \\
\hline & $\begin{array}{l}\text { Standard deviation (second and } \\
\text { third quartiles) }\end{array}$ & & 0.40 & & 0.44 \\
\hline
\end{tabular}

Source: Prepared by the authors based on figures published by the Chilean National Institute of Statistics (INE). 
TABLE 6

Chile: Selected components of the consumer price index basket. Relative positions by distribution of average monthly price growth rates, April 1989 to December 1998

\begin{tabular}{|c|c|c|}
\hline First quartile & Second and third quartiles & Fourth quartile \\
\hline Fruit & Dairy products & Bread \\
\hline \multirow[t]{6}{*}{ Vegetables } & Pasta & Beer \\
\hline & Meat & Eggs \\
\hline & Fish and seafood & \\
\hline & Soft drinks & \\
\hline & Ready meals & \\
\hline & Mortgage/rental & Drinking water \\
\hline \multirow[t]{2}{*}{ Household electrical goods } & Gas and electricity & Private telephone \\
\hline & Household maintenance & \\
\hline \multicolumn{3}{|l|}{ Household equipment } \\
\hline \multirow[t]{6}{*}{ Clothing } & Petrol & Transport and transportation services \\
\hline & Spectacle lenses & $\begin{array}{l}\text { Private-sector medical services and hospitalization } \\
\text { Medicines (vitamins, cough remedies, antihistamines, } \\
\text { cardiovascular, antibiotics) }\end{array}$ \\
\hline & School equipment & Education (basic, intermediate and higher) \\
\hline & & School and other textbooks \\
\hline & Financial costs & Subscriptions \\
\hline & Toys & \\
\hline
\end{tabular}

Source: Prepared by the authors based on figures published by the Chilean National Institute of Statistics (INE). Products are organized by their respective groups.

TABLE 7

Chile: Selected components of the consumer price index basket. Relative positions by distribution of average monthly price growth rates, January 1999 to August 2004

\begin{tabular}{|c|c|c|}
\hline First quartile & Second and third quartiles & Fourth quartile \\
\hline Fruit & Bread & Dairy products \\
\hline \multirow{5}{*}{ Vegetables } & Meat & Eggs \\
\hline & Fish and seafood & \\
\hline & Soft drinks & \\
\hline & Mortgage/rental & Basic services \\
\hline & Mobile telephony & Fixed telephony \\
\hline Computing & Household maintenance & \\
\hline Household electrical goods & Household equipment & \\
\hline \multicolumn{3}{|l|}{ Clothing } \\
\hline & Spectacle lenses & Medical services and hospitalization \\
\hline & $\begin{array}{l}\text { Medicines (cardiovascular, } \\
\text { antibiotics, hypertension) }\end{array}$ & $\begin{array}{l}\text { Medicines (vitamins, cough remedies and } \\
\text { bronchodilators, antidepressants, antihistamines) }\end{array}$ \\
\hline & School equipment & Education (basic, intermediate and higher) \\
\hline & School and other textbooks & \\
\hline Financial costs & Toys & Subscriptions \\
\hline
\end{tabular}

Source: Prepared by the authors based on figures published by the Chilean National Institute of Statistics (INE). Products are organized by their respective groups. 
most) include the prices of the services that are hardest to substitute for in the spending structure; many of these prices are subject to government regulation mechanisms. The importance of these goods and services groups in the consumption baskets of the different social strata varies; the prices of the goods and services in the last decile have a greater weight in overall spending. If a stratum is forced to include fasterrising categories in its spending structure because opportunities for substitution are limited (urban transport, for example), it is less able to purchase products whose prices have fallen. Again, some prices are for services that have become segmented, with very different levels of quality on offer. This means that a more detailed analysis might show differences in the variations of the individual components.

A better picture of the cumulative effect of these variations over time can be obtained by comparing the cumulative variation in the period examined. This is particularly applicable in the second period (when the relative positions of the different products in the price variation rate distribution are more stable) and can be done by observing year-on-year results. With a cumulative variation of $16.6 \%$ in the CPI, prices in the first quartile fell by $9.1 \%$ and those in the first decile by $28.8 \%$, while prices in the fourth quartile rose by $20 \%$ and those in the tenth decile by $34.5 \%$ (see table 4 above). Given that the relative positions of many products stabilized, these differences in variation rates had a major impact on the structure of relative prices. Again, the gap between the cumulative CPI variation rate and the median for the cumulative variation rates of the different products over the period $(16.6 \%$ and $4.3 \%$, respectively) also illustrates the degree of asymmetry in the positions of the different products, as discussed above.

\section{Brazil}

In Brazil, the drop in inflation was also accompanied by a rise in relative dispersion, with the dispersion coefficient for goods and services price variation rates rising sharply from about 0.1 to about 0.6 . Both values are very low and significantly less than Chile's. It should be noted that when monthly variations were averaging some $30 \%$ and $25 \%$, in the July 1989 December 1990 and January 1991-July 1994 periods, the standard deviation never really rose above 3 . The extraordinary indexation of the Brazilian economy and government price-setting, especially in the earlier period, account for these values (tables 8, 9 and 10). ${ }^{25}$
Although the average monthly CPI variation rate is higher than the unweighted average of the variation rates included in $z$, as was the case in Chile, the difference between the two is smaller. This shows that the prices of those products whose variation rates are at the top or bottom of the distribution (first and last deciles) do not have very different weights in the CPI basket. If we work at the product group level (onedigit classification), the dispersion in their price variation rates is not different from the result obtained when all products are considered, except in the August 1999-August 2004 period, when the dispersion in variation rates falls to values characteristic of the earliest periods. Again, when the standard deviation of the core of the distribution (i.e., the second and third quartiles) is examined, this proves to be very stable. Albeit to a very small extent, it is the extremes that account for the changes in the standard deviation of the core when the whole distribution is considered.

Again, the standardized distributions of the variation rates included in $z$ enable us to draw some distinctions, both with Chile and between the periods considered. Oddly enough, the median of these variation rates (when standardized) is skewed to the right in the January 1991-July 1994 period (0.23) and to the left in the August 1994-August 1999 period; the latter situation did not arise in the case of Chile. Again by contrast with Chile, there is considerable symmetry between the first and fourth quartiles in the earliest and latest periods, except in the January 1991July 1994 period, when there is asymmetry towards the right as in Chile. Broadly speaking, these values suggest a smaller variation in the relative prices of the different components of the CPI, and in the respective weighting changes within the basket as a whole (figures 3 and 4).

As table 11 shows, the cumulative variation rates for these goods and services concentrations over the different periods have major effects on relative prices -much more so in many cases than in periods of high inflation. Particularly striking are the major disparities in the 1994-1999 period, when the average variations of the tenth and first deciles differed by a factor of more than 10 (in the following period the factor was still about five).

\footnotetext{
${ }^{25}$ In the case of Brazil, the kurtosis indicators are positive in all the periods analysed, being higher in the January 1991-June 1994 subperiod and the August 1999-August 2004 period, while the skewness indicators are negative in these two periods.
} 
TABLE 8

Brazil: The consumer price index and its components. Some statistical indicators

\begin{tabular}{|c|c|c|c|c|c|c|c|c|c|}
\hline \multirow{2}{*}{\multicolumn{2}{|c|}{ Subperiods }} & \multicolumn{4}{|c|}{ Full breakdown of the products in the CPI } & \multicolumn{4}{|c|}{ One-digit breakdown of the product groups in the CPI } \\
\hline & & $\begin{array}{l}\text { Aug. 1989- } \\
\text { Dec. } 1990\end{array}$ & $\begin{array}{c}\text { Jan. } 1991- \\
\text { Jun. } 1994\end{array}$ & $\begin{array}{l}\text { Jul. } 1994- \\
\text { Jul. } 1999\end{array}$ & $\begin{array}{l}\text { Aug. 1999- } \\
\text { Aug. } 2004\end{array}$ & $\begin{array}{c}\text { Aug. 1989- } \\
\text { Dec. } 1990\end{array}$ & $\begin{array}{l}\text { Jan. } 1991- \\
\text { Jun. } 1994\end{array}$ & $\begin{array}{l}\text { Jul. } 1994- \\
\text { Jul. } 1999\end{array}$ & $\begin{array}{l}\text { Aug. 1999- } \\
\text { Aug. } 2004\end{array}$ \\
\hline CPI & $\begin{array}{l}\text { Average monthly } \\
\text { growth rate } \\
\text { (average monthly } \\
\text { inflation in the } \\
\text { period) }\end{array}$ & 30.86 & 25.81 & 0.96 & 0.71 & 30.86 & 25.81 & 0.96 & 0.71 \\
\hline $\begin{array}{l}\text { Average } \\
\text { monthly price } \\
\text { growth rates } \\
\text { of the products } \\
\text { composing } \\
\text { the CPI }\end{array}$ & $\begin{array}{l}\text { Unweighted } \\
\text { average } \\
\text { Standard } \\
\text { deviation } \\
\text { Coefficient of } \\
\text { variation } \\
\text { Median } \\
\text { Highest value } \\
\text { of the first } \\
\text { quartile of the } \\
\text { distribution } \\
\text { Lowest value } \\
\text { of the fourth } \\
\text { quartile of the } \\
\text { distribution }\end{array}$ & $\begin{array}{r}30.40 \\
3.27 \\
0.11 \\
29.61\end{array}$ & $\begin{array}{r}25.23 \\
3.08 \\
\\
0.12 \\
25.22\end{array}$ & $\begin{array}{l}0.54 \\
0.62 \\
0.72\end{array}$ & $\begin{array}{l}0.39 \\
0.53 \\
0.70\end{array}$ & $\begin{array}{l}2.45 \\
0.08\end{array}$ & $\begin{array}{l}0.72 \\
0.03\end{array}$ & $\begin{array}{l}1.02 \\
0.498 \\
0.48\end{array}$ & $\begin{array}{l}0.66 \\
0.13 \\
0.19\end{array}$ \\
\hline $\begin{array}{l}\text { Number of pro } \\
\text { the CPI basket }\end{array}$ & & 434 & 347 & 347 & 513 & 7 & 7 & 7 & 9 \\
\hline
\end{tabular}

Source: Prepared by the authors based on figures published by the Brazilian Geographical and Statistical Institute (IBGE).

TABLE 9

Brazil: The CPI and the prices of CPI components. Indicators of dispersion in growth rates

\begin{tabular}{|c|c|c|c|c|c|c|c|c|c|}
\hline \multicolumn{5}{|c|}{ Comparison with the CPI (all products composing the CPI) } & \multicolumn{5}{|c|}{ Comparison with the CPI (product groups) } \\
\hline Subperiods & $\begin{array}{l}\text { Aug. 1989- } \\
\text { Dec. } 1990\end{array}$ & $\begin{array}{l}\text { Jan. } 1991- \\
\text { Jun. } 1994\end{array}$ & $\begin{array}{l}\text { Jul. } 1994- \\
\text { Jul. } 1999\end{array}$ & $\begin{array}{l}\text { Aug. 1999- } \\
\text { Aug. } 2004\end{array}$ & Subperiods & $\begin{array}{l}\text { Aug. 1989- } \\
\text { Dec. } 1990\end{array}$ & $\begin{array}{l}\text { Jan. } 1991- \\
\text { Jun. } 1994\end{array}$ & $\begin{array}{l}\text { Jul. } 1994- \\
\text { Jul. } 1999\end{array}$ & $\begin{array}{l}\text { Aug. 1999- } \\
\text { Aug. } 2004\end{array}$ \\
\hline $\begin{array}{l}\text { Average monthly } \\
\text { growth rate of the } \\
\text { CPI (average monthly } \\
\text { inflation in the period) }\end{array}$ & 30.86 & 25.81 & 0.96 & 0.71 & $\begin{array}{l}\text { Average monthly } \\
\text { growth rate of the } \\
\text { CPI (average } \\
\text { monthly inflation } \\
\text { in the period) }\end{array}$ & 30.86 & 25.81 & 0.96 & 0.71 \\
\hline $\begin{array}{l}\text { Dispersion coefficient } \\
\text { (DC) of the monthly }\end{array}$ & & & & & $\begin{array}{l}\text { Dispersion } \\
\text { coefficient (DC) }\end{array}$ & & & & \\
\hline CPI growth rates $(1)$ & 0.77 & 0.38 & 1.14 & 0.78 & $\begin{array}{l}\text { of the monthly CPI } \\
\text { growth rates (1) }\end{array}$ & 0.08 & 0.03 & 0.48 & 0.19 \\
\hline $\begin{array}{l}\% \text { of products whose } \\
\text { monthly growth rates } \\
\text { present } C D>(1)\end{array}$ & 77.0 & 100.0 & 96.3 & 97.3 & $\begin{array}{l}\% \text { of product } \\
\text { groups whose } \\
\text { monthly growth } \\
\text { rates present } \\
\mathrm{CD}>(1)\end{array}$ & 57.0 & 100.0 & 71.4 & 100.0 \\
\hline $\begin{array}{l}\% \text { of products whose } \\
\text { monthly growth rates } \\
\text { present } \mathrm{CD}<(1)\end{array}$ & 23.0 & 0.0 & 3.8 & 2.7 & $\begin{array}{l}\% \text { of product } \\
\text { groups whose } \\
\text { monthly growth } \\
\text { rates present } \\
\mathrm{CD}<\text { (1) }\end{array}$ & 43.0 & 0.0 & 28.0 & 0.0 \\
\hline
\end{tabular}

Source: Prepared by the authors based on figures published by the Brazilian Geographical and Statistical Institute (IBGE). 
TABLE 10

Brazil: Growth rate of the CPI and of the product prices composing it. Statistical indicators of distribution

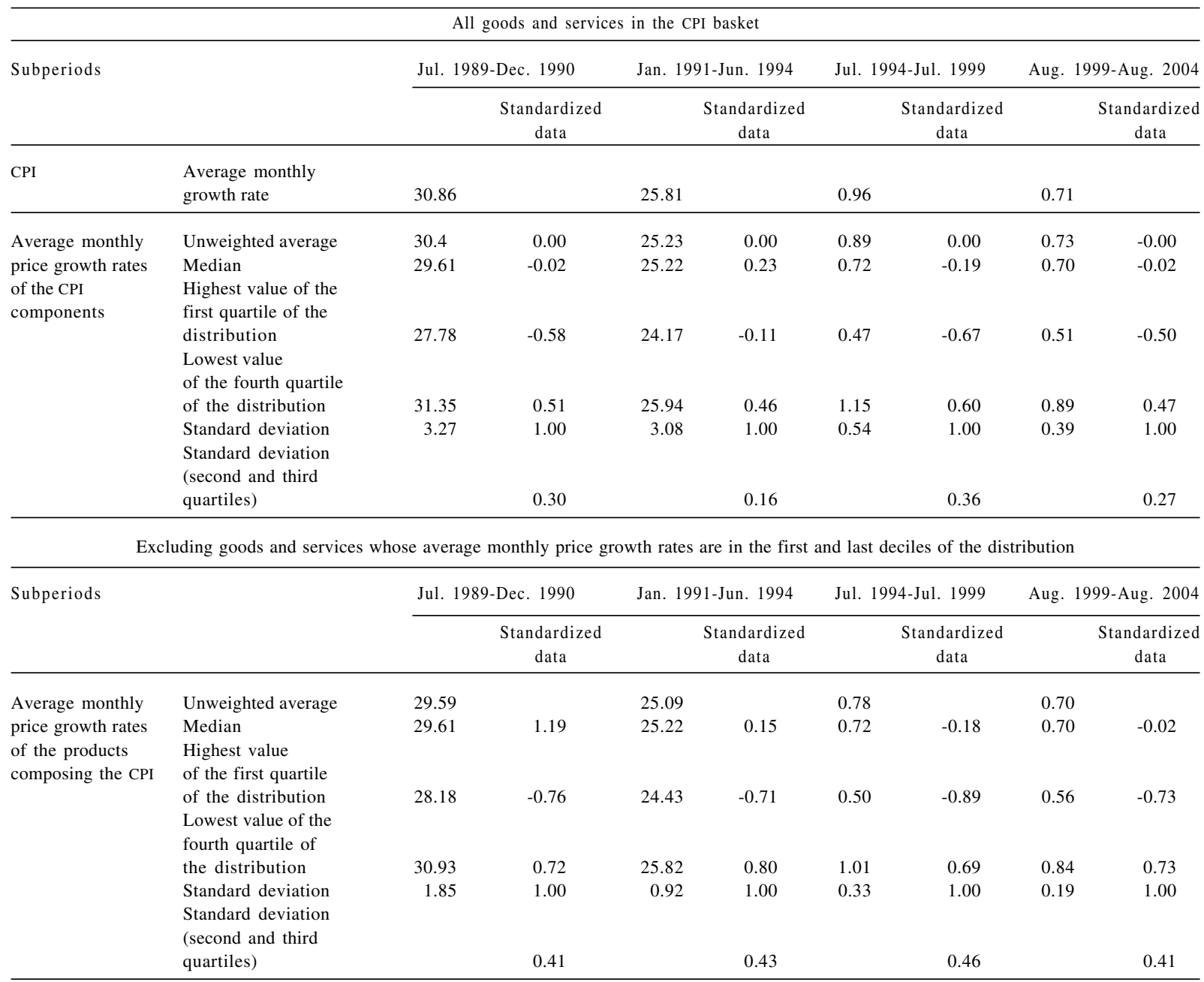

Source: Prepared by the authors based on figures published by the Brazilian Geographical and Statistical Institute (IBGE).

Lastly, the positions of the different components in the $z$ distribution in the last period considered (tables 12 and 13) show some similarities to the situation in Chile, examples being lower price rises for products such as computer and household electrical equipment and clothing, together with some different products such as medical and hospitalization services. At the other extreme, we likewise find the prices of transport and transportation services, and basic services. By contrast with Chile, however, a number of widely consumed foodstuffs appear, such as rice, beans and oil, while education does not. This highlights the powerful effects of certain factors and the range of manoeuvre of others, particularly services provided or regulated by the State, as the price regulation criteria followed can heavily influence inflation levels and dispersion coefficients.

From the above analysis, which is valid for both Chile and Brazil, it may be concluded that the products making up the CPI behave in different ways. While there is a group of goods whose prices consistently rise by 
FIGURE 3

Brazil: Distribution of the average monthly price growth rates of the goods and services composing the CPI basket

(Standardized rates, as percentages)

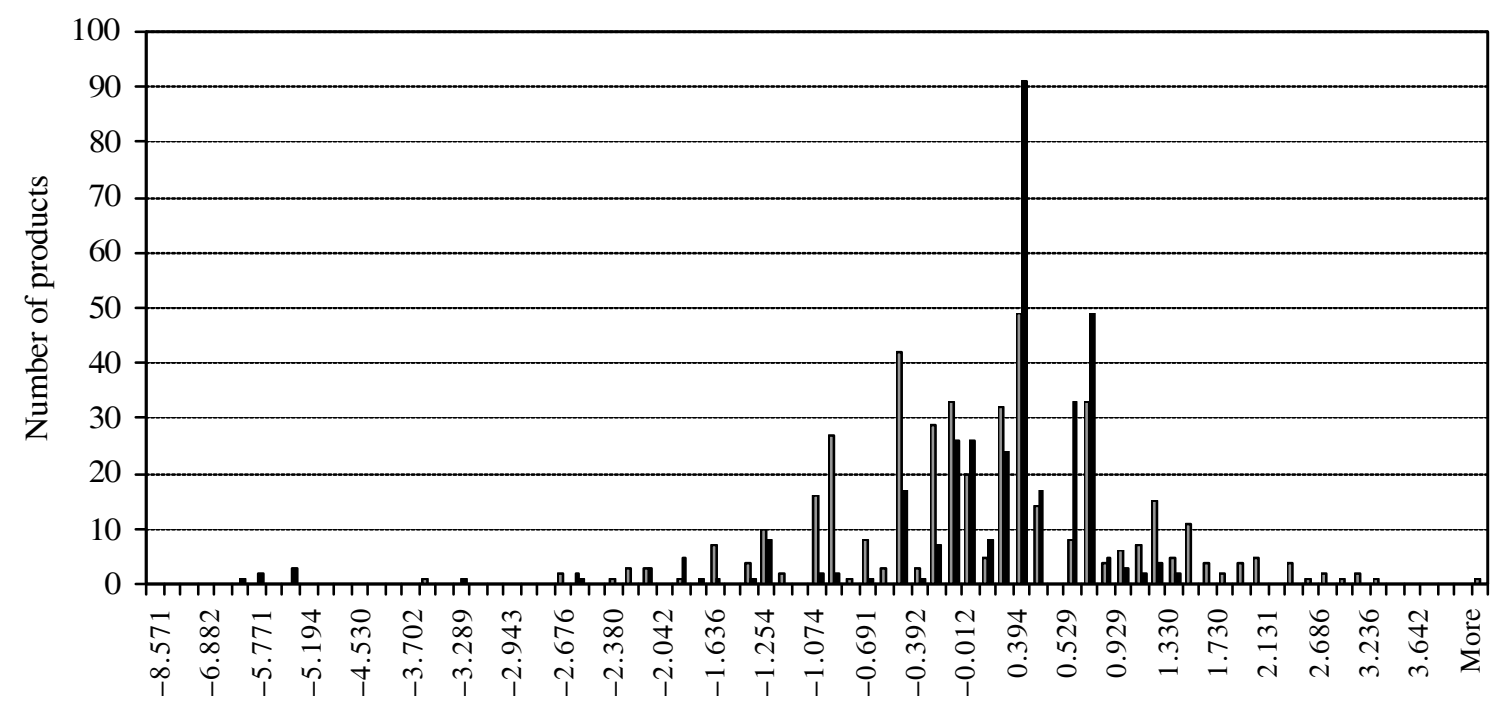

Standardized variation rates

$\square$ Jul. 89-Dec. 90 $\square$ Jan. 91-Jun. 94

Source: Prepared by the authors based on figures published by the Brazilian Geographical and Statistical Institute (IBGE).

FIGURE 4

Brazil: Distribution of the average monthly price growth rates of the goods and services composing the CPI basket

(Standardized rates, as percentages)

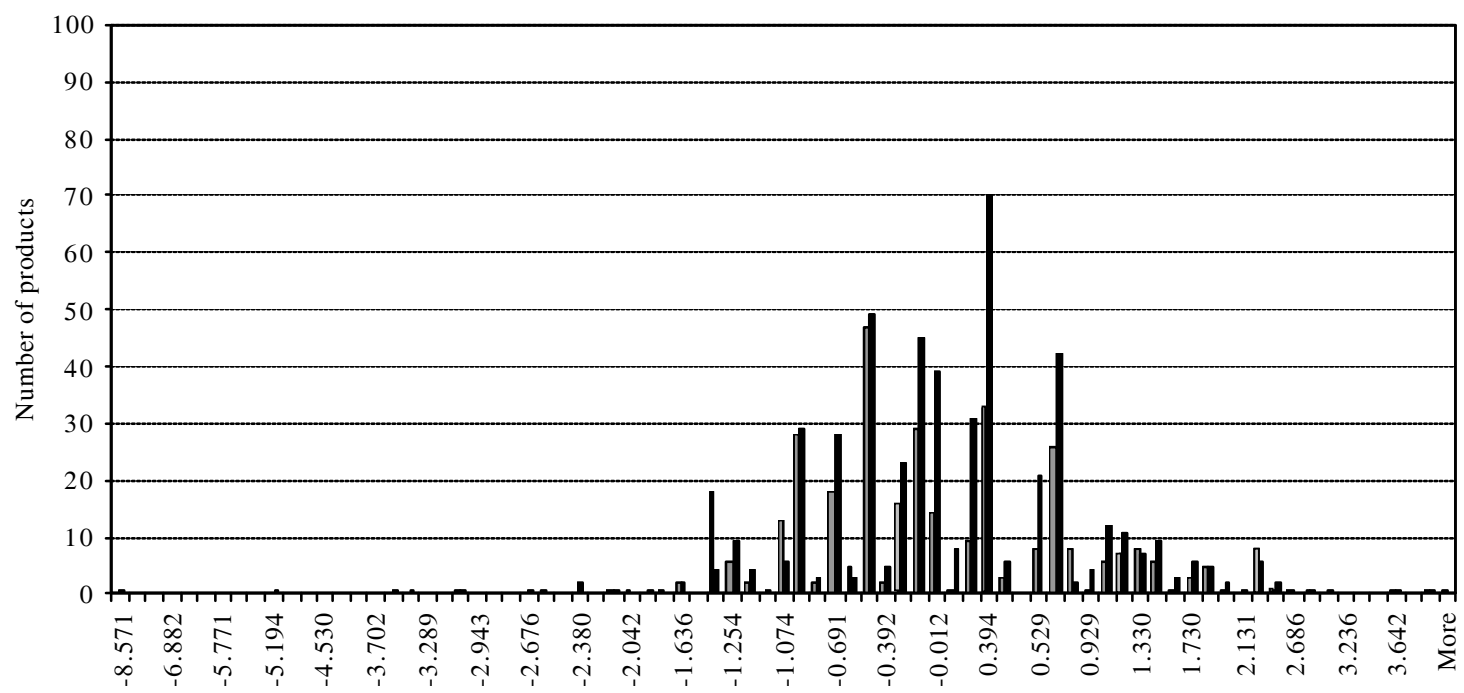

Standardized variation rates

\begin{tabular}{|ll|}
\hline Jul. 94-Jul. $99 \quad$ Aug. 99-Aug. 04 \\
\hline
\end{tabular}

Source: Prepared by the authors based on figures published by the Brazilian Geographical and Statistical Institute (IBGE). 
TABLE 11

Brazil: Growth rate of the consumer price index and of the prices
of its components. Statistical indicators of distribution
(Cumulative rates in the period, as percentages)

\begin{tabular}{|c|c|c|c|c|c|}
\hline & & $\begin{array}{c}\text { August } 1989- \\
\text { December } 1990\end{array}$ & $\begin{array}{c}\text { January } 1991- \\
\text { June } 1994\end{array}$ & $\begin{array}{l}\text { July } 1994- \\
\text { July } 1999\end{array}$ & $\begin{array}{l}\text { August } 1999- \\
\text { August } 2004\end{array}$ \\
\hline CPI & Growth rate in the period & 12556.6 & 1542419.2 & 78.8 & 53.0 \\
\hline \multirow[t]{5}{*}{$\begin{array}{l}\text { Price growth rates } \\
\text { of the products } \\
\text { composing the CPI }\end{array}$} & $\begin{array}{l}\text { Highest value of the first } \\
\text { quartile of the distribution } \\
\text { Lowest value of the fourth }\end{array}$ & 8147.7 & 889932.9 & 30.5 & 35.3 \\
\hline & $\begin{array}{l}\text { quartile of the distribution } \\
\text { Highest value of the first }\end{array}$ & 13446.7 & 1610835.1 & 95.8 & 70.1 \\
\hline & decile of the distribution & 6168.3 & 541176.6 & 12.5 & 21.3 \\
\hline & decile of the distribution & 18156.4 & 1977492.3 & 147.5 & 95.8 \\
\hline & Median & 10560.7 & 1267390.7 & 53.3 & 51.7 \\
\hline
\end{tabular}

Source: Prepared by the authors based on figures published by the Brazilian Geographical and Statistical Institute (IBGE).

TABLE 12

\section{Brazil: Selected components of the consumer price index basket. Relative positions by distribution of average monthly price growth rates, January 1991 to June 1994}

\begin{tabular}{|c|c|c|}
\hline First quartile & Second and third quartiles & Fourth quartile \\
\hline Rice & $\begin{array}{l}\text { Pasta } \\
\text { Flour } \\
\text { Fish and seafood } \\
\text { Meat } \\
\text { Vegetables } \\
\text { Cassava }\end{array}$ & $\begin{array}{l}\text { Black beans } \\
\text { Potatoes } \\
\text { Vegetables } \\
\text { Dairy products }\end{array}$ \\
\hline $\begin{array}{l}\text { Rental/condominium } \\
\text { costs }\end{array}$ & Basic services & \\
\hline $\begin{array}{l}\text { Household electrical } \\
\text { appliances }\end{array}$ & Household equipment & \\
\hline & $\begin{array}{l}\text { Taxi, bus, petrol } \\
\text { New cars }\end{array}$ & Aircraft, metro \\
\hline
\end{tabular}

Source: Prepared by the authors based on figures published by the Brazilian Geographical and Statistical Institute (IBGE). Products are organized by their respective groups.

less than the overall CPI (clothing and household equipment, for example), others consistently rise by more (education, health and transport services, for example). The behaviour of food prices varies. All this occurs in the context of a general deceleration in the CPI inflation rate. 
TABLE 13

Brazil: Selected components of the CPI basket. Relative positions by distribution of average monthly price growth rates, August 1999 to August 2004

\begin{tabular}{|c|c|c|}
\hline First quartile & Second and third quartiles & Fourth quartile \\
\hline & $\begin{array}{l}\text { Fruit } \\
\text { Flour } \\
\text { Fish and seafood } \\
\text { Meat } \\
\text { Coffee } \\
\text { Cheese } \\
\text { Beer } \\
\text { Ready meals }\end{array}$ & $\begin{array}{l}\text { Beans } \\
\text { Potatoes } \\
\text { Vegetables } \\
\text { Meat } \\
\text { Cooking oil }\end{array}$ \\
\hline $\begin{array}{l}\text { Computing } \\
\text { Household electrical appliances }\end{array}$ & $\begin{array}{l}\text { Household maintenance equipment } \\
\text { Household equipment }\end{array}$ & \\
\hline Clothing & $\begin{array}{l}\text { Rental/condominium costs } \\
\text { Taxi, train, boat, metro }\end{array}$ & $\begin{array}{l}\text { Coal, gas and electricity, water services } \\
\text { Transport and transportation services } \\
\text { Bus, plane, tolls, petrol, alcohol, diesel } \\
\text { Mail, fixed-line telephony }\end{array}$ \\
\hline \multicolumn{3}{|c|}{ Medical and hospitalization services } \\
\hline Personal services & $\begin{array}{l}\text { Recreational items and hotels } \\
\text { Education } \\
\text { School equipment } \\
\text { Public telephones, mobile telephony, } \\
\text { Toys }\end{array}$ & cable TV \\
\hline
\end{tabular}

Source: Prepared by the authors based on figures published by the Brazilian Geographical and Statistical Institute (IBGE). Products are organized by their respective groups.

\section{VI \\ Regional tendencies judged in the light of the results and conclusions from Chile and Brazil}

The tendencies described above were identified by analysing the relative positions by price variation rate of the different components of the CPI in Chile and Brazil, but they can be extended, up to a point, to the countries of the region generally. Although we could not obtain full information on all the components of their respective CPI baskets, when we looked at the evolution of consumer price indices in other Latin American countries ${ }^{26}$ by considering the overall index

\footnotetext{
${ }^{26}$ The countries referred to are: Argentina, Bolivia, Colombia, Costa Rica, Ecuador, Mexico, Peru, Uruguay and the Bolivarian Republic of Venezuela.
}

and the goods and services groups composing it (onedigit classification), some of the same tendencies reemerged. ${ }^{27}$

To compare the evolution of price variation rates in the different product groups making up the CPI, we calculated the average monthly rates of increase in the respective price indices and then standardized them, thus making the distribution parameters comparable both between countries and between periods. As in the

\footnotetext{
27 The analysis was carried out by calculating average monthly variation rates for both the overall consumer price index and the goods and services groups composing it, in different time periods.
} 
cases of Chile and Brazil, the periods chosen were usually ones in which the same basket of goods was used. In cases where major economic events occurred at particular points in time, however, such as a significant devaluation in the national currency, the periods concerned were split into subperiods so that the behaviour of aggregate prices could be observed and compared (by product group) at times of particular interest for economic analysis. The results are shown in figure 5 .

Because the monthly variation rates in figure 5 are standardized, ${ }^{28}$ the number of the ordinate indicates standard deviations from the average monthly variation, and not inflation rates. A negative standard deviation represents products whose variations were lower than average and led the downward tendency. For some countries where very low inflation was achieved in the periods analysed, negative deviations represent negative rates of absolute growth. Conversely, positive deviations represent products whose prices rose by more than the average and on occasion, such as in post-devaluation periods, were responsible for raising inflation.

Figure 5 shows some significant phenomena. The general idea is to see which product groups experienced (standardized) variations persistently in excess of the average, or whether there were fluctuations, and if so how large they were. Starting in the early 1990s, prices for clothing and for the household equipment considered tended to rise by less, and in some cases significantly less, than the CPI as a whole. In cases where the prices for these products rose by more than the CPI, this tended to happen in periods when there was a significant devaluation in the national currency. The sharp devaluations of the Argentine and Uruguayan currencies in early 2002, for example, led to a moderate rise in inflation that year and a large shift in relative prices (in Uruguay, this happened with household equipment). Devaluation, combined with a pick-up in domestic demand from the low levels it had reached after the recessions in these countries, led to a

\footnotetext{
28 To standardize the average monthly variation rates, the average of the monthly price variation rates of the different product groups was subtracted from the average monthly price variation rate of each of the groups and the result was divided by the standard deviation of the average monthly price variation rates of the product groups. The calculation did not take account of the average monthly CPI variation rate, since this is obtained by combining the weighted price variation rates of the different product groups.
}

recovery in the prices of these products, which rose by about the same as or more than the CPI. Something similar happened in Mexico after the devaluation of late 1994.

Prices for services generally have increased by more than the CPI. However, both the type of services and the scale of price rises have varied from one country to another. For certain countries in particular periods the position of service sector prices relative to goods prices has been influenced by fluctuations in the local currency, particularly when there have been large devaluations; these have made goods significantly more expensive as prices for imported goods or for inputs used to produce finished goods within the country have risen, or margins for domestic products have widened. In other countries, particularly those that are more dependent on imports to supply them with oil and fuels, higher prices for transportation services have been significantly influenced in recent years by high international oil prices and the tendency for State subsidies to be abolished.

The prices of basic services have also shown a clear upward trend in many countries, owing not only to higher fuel costs but also to concession and privatization decisions made by the relevant authorities. In other countries and/or periods, however, the authorities have chosen to provide subsidies or regulate tariffs for these same services, and prices have risen more slowly than the CPI as a result.

Another aspect that can influence variations in services prices is the methodology used to compile the price data and then include them in the general CPI calculation. In Colombia, for example, prices in the housing category mainly reflect the value of rents imputed to families. Because these notional rents stay fairly stable and have a large weighting in the overall CPI, their influence on relative prices and the overall CPI is large.

Given all this, it is possible to arrive at some conclusions concerning the evolution of relative prices for the components of CPI baskets in the countries observed. First, the data mentioned show that, in very aggregate terms, there has not been a homogeneous trend in prices as there was, for example, in Brazil during the 1991-1994 period examined earlier. ${ }^{29}$ Not all goods prices are falling in relative terms (where prices are falling is for semi-durable goods, such as

\footnotetext{
29 This was a period when the rate of increase in the price index slowed significantly.
} 
FIGURE 5

\section{Latin America (11 countries): Average monthly price growth rates of the product groups composing the CPI \\ (Standardized data)}

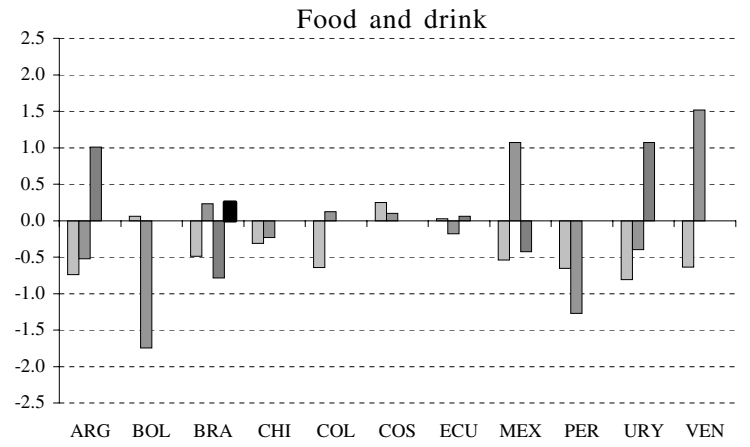

Clothing

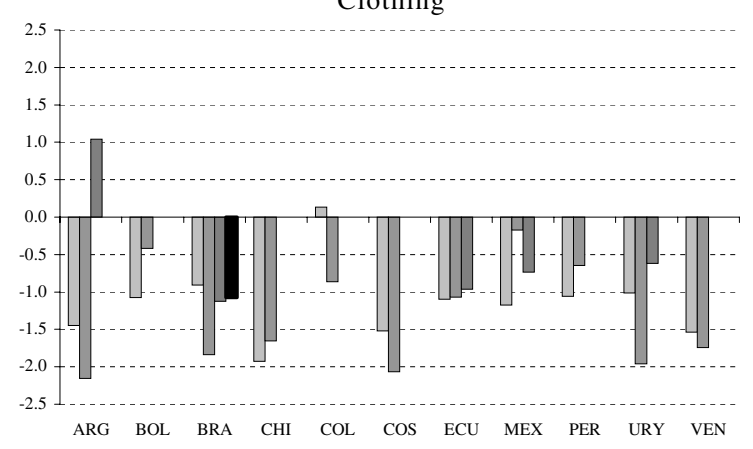

Housing and basic services

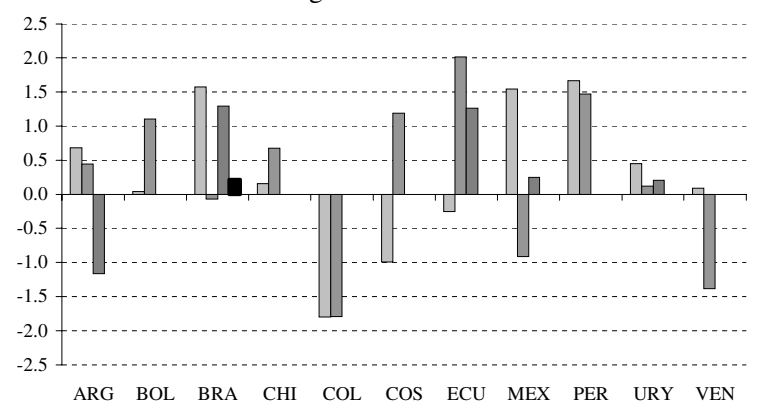

\begin{tabular}{lclll}
\hline & Period 1 & Period 2 & Period 3 & Period 4 \\
\hline Argentina & $1989-1992$ & $1993-2001$ & $2002-2004$ & \\
Bolivia & $1989-1998$ & $1999-2004$ & & \\
Brazil & $1989-1990$ & $1991-$ jun 1994 & jul 1994-1998 & 1999-2004 \\
Chile & $1992-1998$ & $1999-2004$ & & \\
Colombia & $1989-1998$ & $1999-2004$ & & \\
Costa Rica & $1995-1998$ & $1999-2004$ & & \\
Ecuador & $1989-1996$ & $1997-1999$ & $2000-2004$ & \\
Mexico & $1989-1994$ & $1994-1998$ & $1999-2004$ & \\
$\begin{array}{l}\text { Peru } \\
\text { Uruguay }\end{array}$ & $1990-1998$ & $1999-2004$ & & \\
$\begin{array}{l}\text { Venezuela } \\
\text { (Bol. Rep. of) }\end{array}$ & $1999-1998$ & $1999-2001$ & $2002-2004$ & \\
\hline
\end{tabular}

Source: Prepared by the authors from official statistics.
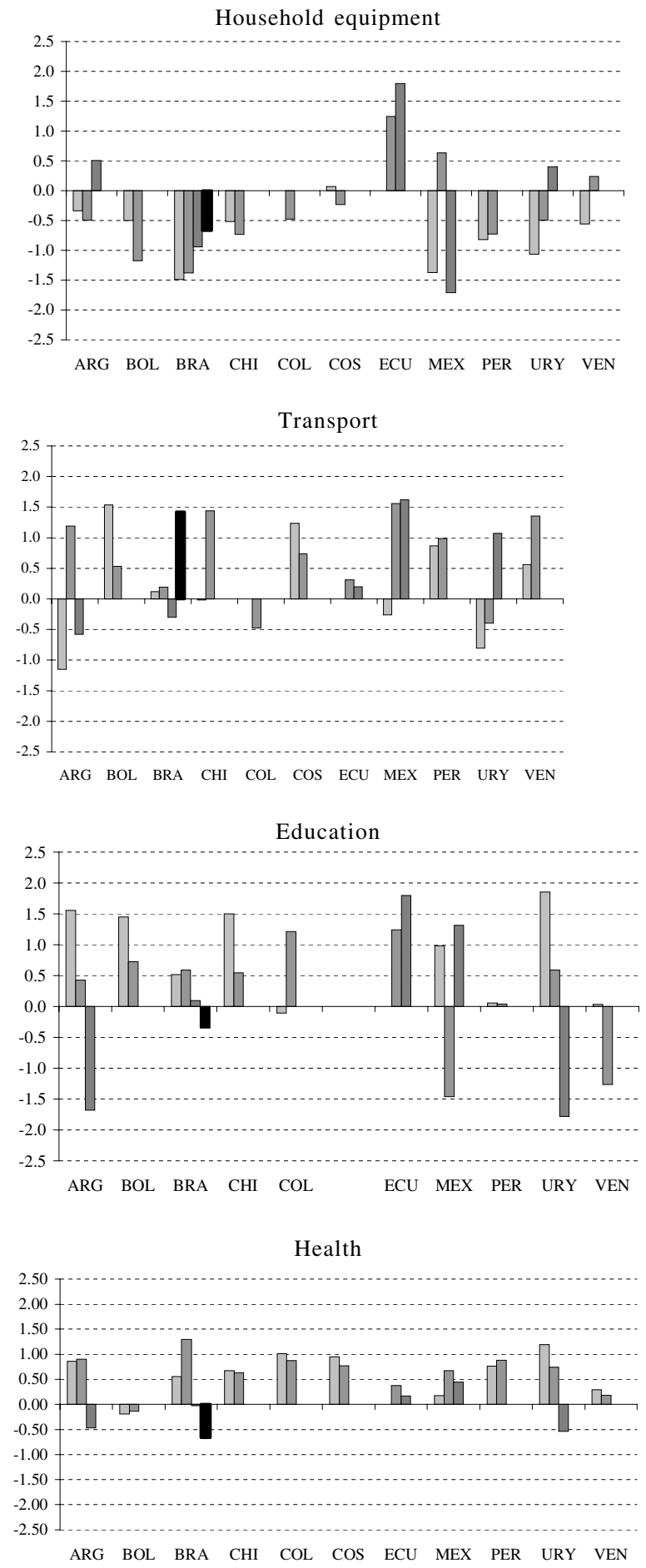

$\square$ Period 1 $\square$ Period 2 $\square$ Period 3 $\square$ Period 4 
clothing and footwear, textiles and household equipment). Food prices are rising in a number of countries, ${ }^{30}$ as are prices for a number of services. The largest prices increases have been for education, health and transport services and basic services. Prices for personal services and "other services", meanwhile, have not risen as much, so that not all service prices have behaved alike.

Another tendency that recurs to a greater or lesser degree among the countries analysed is that low CPI inflation is not necessarily accompanied by low dispersion in the prices of the different goods and services groups. On the contrary, when the dispersion coefficients for the highest- and lowest-inflation periods are compared, it transpires that in all the countries analysed this coefficient is higher when inflation is at lower levels. This is illustrated by the data in table 14, which show that in periods when the countries' inflation was reasonably low (a cumulative $2 \%$ to $3 \%$ a year), the dispersion coefficient for the prices of the different goods and services groups making up the overall CPI was higher than the coefficient for periods when average inflation was above these rates.

Although the difference between average inflation rates in the product groups making up the CPI and the overall CPI inflation rate is generally small in the different periods, there are exceptions. In addition, the

TABLE 14

Latin America (selected countries): Relationship between consumer price index growth rates and those of the product groups composing the CPI

(Average monthly growth rates in the period and statistical indicators)

\begin{tabular}{|c|c|c|c|c|c|c|c|c|c|c|c|}
\hline & & $\begin{array}{l}\text { CPI } \\
(1)^{\mathrm{a}}\end{array}$ & $\begin{array}{l}\text { Product } \\
\text { groups } \\
(2)^{b}\end{array}$ & $\begin{array}{l}\text { Deviation } \\
((1) /(2))-1\end{array}$ & $\begin{array}{l}\text { Coefficient of } \\
\text { variation }^{c}\end{array}$ & & & $\begin{array}{l}\text { CPI } \\
(1)^{\mathrm{a}}\end{array}$ & $\begin{array}{l}\text { Product } \\
\text { groups } \\
(2)^{\mathrm{b}}\end{array}$ & $\begin{array}{r}\text { C } \\
\text { Deviation } \\
((1) /(2))-1\end{array}$ & $\begin{array}{l}\text { Coefficient of } \\
\text { variation }^{c}\end{array}$ \\
\hline \multirow[t]{3}{*}{ Argentina } & 1989-1992 & 13.90 & 14.35 & -0.03 & 0.09 & \multirow[t]{3}{*}{ Ecuador } & 1989-1996 & 2.71 & 2.71 & 0.00 & 0.08 \\
\hline & 1993-2001 & 0.09 & 0.09 & -0.08 & 1.80 & & 1997-1999 & 5.61 & 5.78 & -0.03 & 0.16 \\
\hline & 2002-2004 & 1.32 & 1.23 & 0.07 & 0.40 & & 2000-2004 & 1.75 & 1.71 & 0.02 & 0.34 \\
\hline \multirow[t]{3}{*}{ Bolivia } & 1989-1998 & 0.86 & 0.86 & 0.01 & 0.12 & \multirow[t]{3}{*}{ Mexico } & 1989-1994 & 1.22 & 1.22 & 0.00 & 0.28 \\
\hline & 1999-2004 & 0.24 & 0.30 & -0.21 & 0.31 & & 1994-1998 & 2.06 & 2.02 & 0.02 & 0.10 \\
\hline & & & & & & & 1999-2004 & 0.54 & 0.54 & -0.01 & 0.31 \\
\hline \multirow[t]{3}{*}{ Brazil } & 1989-1990 & 29.39 & 29.36 & 0.00 & 0.07 & \multirow[t]{3}{*}{ Peru } & 1990-1998 & 5.98 & 6.15 & -0.03 & 0.11 \\
\hline & 1991-jun 1994 & 25.85 & 25.83 & 0.00 & 0.03 & & 1999-2004 & 0.21 & 0.28 & -0.26 & 0.47 \\
\hline & jul $1994-1998$ & 0.99 & 1.16 & -0.14 & 0.57 & & & & & & \\
\hline \multirow[t]{3}{*}{ Chile } & 1992-1998 & 0.68 & 0.69 & -0.02 & 0.51 & \multirow[t]{3}{*}{ Uruguay } & 1989-1998 & 3.44 & 3.51 & -0.02 & 0.09 \\
\hline & 1999-2004 & 0.23 & 0.15 & 0.52 & 2.28 & & 1999-2001 & 0.35 & 0.33 & 0.07 & 0.64 \\
\hline & & & & & & & 2002-2004 & 1.27 & 1.15 & 0.10 & 0.25 \\
\hline \multirow[t]{2}{*}{ Colombia } & 1989-1998 & 1.73 & 1.77 & -0.02 & 0.15 & \multirow{2}{*}{$\begin{array}{l}\text { Venezuela } \\
\text { (Bol. Rep. of) }\end{array}$} & 1990-1999 & 3.13 & 3.26 & -0.04 & 0.13 \\
\hline & 1999-2004 & 0.62 & 0.63 & -0.02 & 0.39 & & 2000-2004 & 1.59 & 1.52 & 0.04 & 0.19 \\
\hline \multirow[t]{2}{*}{ Costa Rica } & $1995-1998$ & 1.04 & 1.03 & 0.01 & 0.22 & & & & & & \\
\hline & 1999-2004 & 0.85 & 0.82 & 0.04 & 0.28 & & & & & & \\
\hline
\end{tabular}

Source: Prepared by the authors from official statistics.

a $(1)=$ Average monthly growth rate of the consumer price index in the period.

$\mathrm{b}(2)=$ Mean of the average monthly price growth rates of the goods and services composing the CPI basket.

c Coefficient of variation for the average monthly price growth rates of the different product groups composing the CPI basket.

\footnotetext{
30 There are possible reasons for this. Explanations may include international price trends for some foods; the degree to which the food products included in the consumption basket are processed, as this is closely related to a country's consumption patterns,
}

particularly among the high- and middle-income groups which have the greatest influence on the structure of the CPI; weather conditions that affect farm production; or phytosanitary regulations in countries that limit trade in fresh foods (including imports). 
analysis carried out for Chile and Brazil showed that greater product disaggregation brought more marked differences to light.

The information presented provides at least a partial answer to the questions formulated earlier. Not only did the dispersion coefficient not fall with inflation, but it actually rose considerably. Again, even though fairly low on an annual basis, inflation becomes significant when the differences in price variations between the first and last deciles and quartiles in several years are added together. Perhaps most importantly, there were homogeneous product groups that stayed in these extreme deciles and quartiles year after year, giving a stable direction to relative prices changes -something that was unusual in the region in earlier periods.

This price behaviour raises questions that, while not the main focus of this article, do point to further research. To what extent do these price variations reflect a reallocation of resources due to the growing liberalization of the international economy? Or are they the result of public policies, especially those for service sectors, which do after all sometimes follow divergent approaches from country to country? What role is being played in price regulation policies by the growing economic power of certain actors that are dominating larger and larger percentages of markets through mergers and acquisitions? What influence are government-applied price regulation policies having? How do price regulation policies affect the leeway of central banks when they come to set monetary policy? Can CPI weightings or poverty line structures be kept stable in the medium and long term in the face of these variations in relative prices? Do we know enough about the scope for substitution in the consumption baskets of the different social strata for different product groups at the present time? Where products that account for a large share of spending by the poorer strata have risen in price by much more than the average, is it right to use the consumer price index as a benchmark for wage settlements without altering CPI weightings that have stayed the same for years?

We shall now explore some of the issues surrounding these questions: first, the factors that underlie both inflation developments and changes in relative prices and, second, the potential need for governments to have a relative price strategy. It is important for these aspects to be considered when policy is made in this area.

\section{VII}

\section{The main factors associated with price developments in consumer price indices}

Broadly speaking, a range of factors underlie price shifts. These include technological change, the evolution of demand, the availability and allocation of resources, and the configuration of markets. These factors can be modified by public policies. In the 1990s and early 2000s, particular emphasis was placed on the consequences of policies that opened up national economies to the outside world. Indeed, there is now a quite intense debate about the effects of this liberalization on different prices (for example, the way workforces in markets as different as China and Germany, with such contrasting laws, practices and demographic situations, are made to compete in the international market). There is also thinking going on about changes in the price of capital and in the relative prices of capital and labour in a new context: the massive influx of workers into the global market because of this new economic openness. ${ }^{31}$
This study has shown the effects of trade liberalization on the prices of a range of goods, including the beneficial downward pressure this has placed on price indices and the major shifts in relative prices it has caused.

The policies adopted by transnational companies, driven by their cost structure or location policies and their handling of production or sales, have had similar effects. One example of this is the fall in international prices for final consumption goods as a result of higher productivity or lower labour costs; this development has been most visible in the cases of clothing, textiles and footwear, some household equipment and certain products used for education and recreation, such as toys, stationery and everything connected with computing.

\footnotetext{
${ }^{31}$ See The Economist (2005).
} 
Opening up economies also led to changes in the supply of goods. The new prices clearly affected the production structure, the distribution of employment, wages and the balance of payments, depending on the country. Every time a trade liberalization treaty is signed, there are different effects on the different agents in this new relative price structure. What we are trying to emphasize here is that the new prices have had a major impact, that they did not originate independently of the policy measures adopted, and that their consequences can be structural. This is a factor, then, that helps to hold down inflation and increase the welfare of those who benefit from lower relative (and sometimes absolute) goods prices, but that has very disparate effects on different social and productive strata.

Another development that had major effects on inflation and relative prices was de-indexation, which bore down significantly on inertial inflation. This happened because de-indexation broke the mechanisms whereby past inflation determined expectations of future inflation. In periods of high inflation, of course, corporate price adjustment strategies could be vital to survival, and widespread indexation, like that used in Brazil in some periods, ensured that relative price changes would be kept within limited ranges. As we demonstrate below, however, the phasing out of indexation was accompanied by new factors that worked in combination with the price adjustment strategies of agents. Nonetheless, some products have continued to be indexed in one way or another, and this has influenced relative prices.

Fiscal policy decisions have influenced changes in the relative prices of some goods and services. At the same time, fiscal policy has generally been constrictive in most Latin American countries. Decisions concerning the size and coverage of subsidies have also affected relative prices. Education and health services are examples of this: these were normally subsidized in the past in many of the region's countries, but have now been privatized to some extent in many of them, and prices have accordingly risen.

Transport prices, meanwhile, are increasingly reflecting international developments in fuel prices. In many countries, nonetheless, the economic authorities subsidize or cap the prices paid by consumers. In almost all the countries, again, changes in basic service prices are determined by governmentset caps on the prices charged to consumers. Thus, price developments in these areas are partially determined by government fiscal and social policy decisions, and particularly by the level of investment returns deemed acceptable.

Another important factor has been the handling of monetary and exchange-rate policy in the region's countries. The use of inflation targeting programmes, with all their consequences for interest rates and their possible impact on economic activity, has been reflected in the evolution of consumer prices. A very interesting debate on the subject is now in progress in a number of Latin American countries, centring on the explicit relationship between inflation and monetary policymaking which makes the latter dependent on domestic price changes. In cases like this, if monetary policy is run by central banks (which in many countries are autonomous bodies with independent decisionmaking powers), and if the explicit objective of bringing or keeping down inflation is inflexible and the rates pursued are very low, it is possible that this form of management may hinder economic recovery at certain times and be incompatible with the economic stimulation objectives pursued by the government authorities. In particular, though, these policies affect certain prices and not others (regulated ones, for example), so that they also have the effect of altering relative prices.

Many countries in Latin America have used exchange rates as a way of controlling inflation. The result has often been an overvalued currency, ultimately making the relationship between tradable and non-tradable goods prices unsustainable. In cases where relative price shifts have created major imbalances in the balance of payments and the exchange rate has become impossible to maintain, relative prices have been corrected by sharp devaluations that have favoured goods (essentially tradable) over services (generally non-tradable). This has happened to very differing degrees from one country to another, however, and has usually marked a departure from the historical norm. In any event, this is a policy measure that has influenced both relative prices and inflation, and the effects can linger and indeed intensify over time.

Another important factor has been the ability of wholesalers to pass on price rises to retailers and consumers when domestic currencies have devalued or the international price of particular products has increased. Whether or not they can do so is largely determined by domestic demand, and in particular private consumption, in the Latin American countries. Underlying the behaviour of relative prices is the fact 
that these countries' growth has largely been based on the development of their external sector, while domestic demand has expanded at a considerably more modest pace. This clearly constrains inflationary pressures. Examples include the indicators of both investment and private consumption by families in recent years. From 1998 to 2003, gross fixed capital formation fell by $10.9 \%$ in real terms, while in 20022003 private consumption was about $0.5 \%$ lower than in 2001. In addition, mergers and acquisitions, especially in the commerce sector, shifted the relative power of commerce and production in markets, along with the margins for the two activities. Thus, this factor affected both inflation and relative prices.

This last factor is also reflected in differences in the variation rates of consumer price indices and

\section{VIII}

\section{Conclusions}

This article has looked at the evolution of relative prices in various periods during the 1990s and early 2000s. It has analysed the relationship between falling inflation and changes in dispersion, as measured by the dispersion coefficient, in the price variations of the different goods and services. It has shown that lower inflation was accompanied in most cases by greater dispersion, a situation that contrasts with earlier experience in other countries. The scale of this dispersion has been identified and, perhaps most importantly, it has been shown that homogeneous product groups maintained a fairly stable presence in the top and bottom deciles and quartiles of the price variations, a subject not addressed in earlier research.

It is thus clear that lower inflation coincided with significant policy changes that led to structural shifts in the workings of the countries' economies. This has produced a new set of relatives prices which, by contrast with what happened in the past, are targeted at the level of the individual goods and services groups. Not enough thought seems to have been given to the broader relative price situation that has ensued.

The relative price shifts associated with the developments described have undoubtedly influenced the allocation of resources and welfare in the different social strata. In the different productive branches, production functions, cost structures, the balance wholesale price indices. While it is true that they cannot be accurately compared, ${ }^{32}$ their evolution provides an idea of how they are behaving. This being so, the different behaviour of the two indices could be indicative of one of the following situations: a time lag, in which case rises in wholesale prices could be transferred to consumer prices in the near future; a decision by wholesalers to reduce their margins (chiefly owing to low consumer demand) to levels that are still profitable but do not pass on price increases to consumers in full; and, lastly, a decision by wholesalers to maintain their margins but change the mix of goods they supply, favouring domestic or imported products as relative prices dictate and holding down or even cutting prices for the consumer.

between domestic and imported goods, and occupational density have all shifted. They therefore merit more attention than they have received. Those responsible for the national accounts could help clarify the effects of the new relative prices by focusing on these changes in their own publications. The developments described have been accompanied by a shift in the way the role and importance of relative prices are perceived. It is now generally agreed that price stability policies which use the CPI variation rate as an indicator have become preponderant in public policies and particularly in the monetary policies of central banks. At the same time, as we have pointed out, not enough thought has been given to the broader relative price situation when economic policy has been planned.

The information presented shows that aggregate CPI figures are the outcome of quite opposing tendencies and that CPI variations have been accompanied by substantial changes in the relative prices of homogeneous groups of these indices' components. At the lower end of the distribution are goods and services that are more responsive to trade liberalization measures, the exchange rate and price falls influenced by changes in the structure of the world

32 These indices have different baskets and coverage; the wholesale price index contains only goods. 
supply of tradable goods, and that are more sensitive to the fluctuations of the global economy and the consequences of these for the balance of payments and exchange rate. Broadly speaking, these products made a major contribution to lower inflation from the mid1990s to the mid-2000s. At the upper end are products affected by the application of liberalization policies to service provision and by concessions of various kinds; in the case of concessions, governments have followed quite disparate price-setting criteria, but the overall effect on prices has been upward. Here, pricing is the outcome of public policies in which monetary policy has played only a small part. Fuels are also at the upper end of the scale, the main recent influences in this case being liberalization and ever-increasing price rises, with public policy playing a more passive role than in the past. All these items have tended to lift inflation. In the core of the distribution are the goods and services which are most likely to be affected by monetary policy and whose prices relative to those at the top and bottom shift as a result of this. ${ }^{33}$ Thus, inflation developments cannot be separated from two types of factors in which policies other than monetary policy, each with its own objective, play a significant role. As we have said, this has given rise to some debate about the scope and influence of monetary policy.

At the same time, structural changes in economies have led to alterations in income distribution and the structure of supply. We have seen the emergence of consumption patterns which differ significantly between the different social strata, and in which the relative price structure plays an important role. The scope for substitution in CPI baskets varies greatly, so that certain sectors of society have fewer opportunities to take advantage of more slowly rising prices to increase their welfare. The CPI weightings and baskets used to determine poverty lines are slow to reflect these phenomena because their structure changes only over the long term. Nonetheless, growing political pressure from the worst-affected groups is highlighting the need to consider relative prices in their entirety.

In these circumstances, the supposed independence of individual policies designed for specific important ends is questionable, since they actually have residual effects on the range of action of monetary policy and, in particular, varying effects on the welfare of the different social strata, as these have very different incomes and a very different capacity to react to relative price changes. In our opinion, the scale of relative price shifts calls for research to provide a better quantification of the effects they have been causing. It is also worth asking whether the changes identified will maintain their tendency or whether the factors underlying them will weaken or alter (one example being the shift from recession in the early 2000s to a period of expansion like 2004-2006).

\footnotetext{
33 The products in the highest and lowest quartiles and in the core are described in sections $\mathrm{V}$ and VI.
} 
APPENDIX

\section{V matrix}

Price indices

\begin{tabular}{|c|c|c|c|c|c|}
\hline & $t_{0}$ & $t_{1}$ & $\ldots$ & $\ldots$ & $t_{m}$ \\
\hline CPI & $I_{\text {CPI }}$ & $I C P I I$ & $\ldots$ & $\ldots$ & $I_{C P I}{ }_{m}$ \\
\hline$P_{1}$ & $I P_{1 o}$ & $I P_{11}$ & $\ldots$ & $\ldots$ & $I P_{1 m}$ \\
\hline$P_{2}$ & $I P_{2 o}$ & $I P_{21}$ & $\ldots$ & $\cdots$ & $I P_{2 m}$ \\
\hline$\cdot$ & . & . & $\ldots$ & $\ldots$ & . \\
\hline$\cdot$ & . & . & $\cdots$ & $\cdots$ & . \\
\hline$\cdot$ & $\cdot$ & . & $\ldots$ & $\ldots$ & . \\
\hline$P_{n}$ & $I P_{n o}$ & $I P_{n 1}$ & $\ldots$ & $\ldots$ & $I P_{n m}$ \\
\hline$M$ & $M_{0}=\left(\sum I_{P_{i o}}\right) / n$ & $M_{1}=\left(\sum I_{P_{i} 1}\right) / n$ & $\ldots$ & $\ldots$ & $M_{m}=\left(\sum I_{P_{i m}}\right) / n$ \\
\hline
\end{tabular}

A

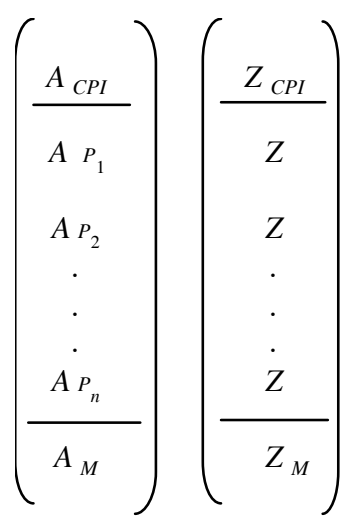

$\mathrm{V}$ is a matrix of monthly price indices in which:

$C P I$ is the consumer price index published by the country

$P_{i} \quad$ represents the goods and services (products) making up the basket used by the country to compile the CPI in each of the periods

The $A$ and $Z$ vectors were produced as follows:

$$
A=\left(\begin{array}{c}
A_{C P I}=\left(I_{C P I} / I_{C P I O}\right)-1 \\
A P_{1}=\left(I P_{1 m} / I P_{10}\right)-1 \\
A P_{2}=\left(I P_{2 m} / I P_{20}\right)-1 \\
\cdot \cdot \\
\cdot \cdot \\
A_{n}=\left(I P_{n m} / I P_{n 0}\right)-1 \\
A_{M}=\left(M_{m} / M_{0}\right)-1
\end{array}\right)
$$

The following indicators were caldulated for the data included in the $\mathrm{Z}$ vector:

1) The unweighted mean of the average monthly variation rate for all the goods and services making up the CPI basket
$M \quad$ is the unweighted average of all the $P_{i}$ price indices

$A$ is a vector containing the cumulative variation rates for the period covered by the CPI, each of the $P_{i}$ and $\mathrm{M}$

$Z \quad$ is a vector containing the average monthly variation rates of the period covered by the CPI, each of the $P_{i}$ and M

$t$ is time, measured in months

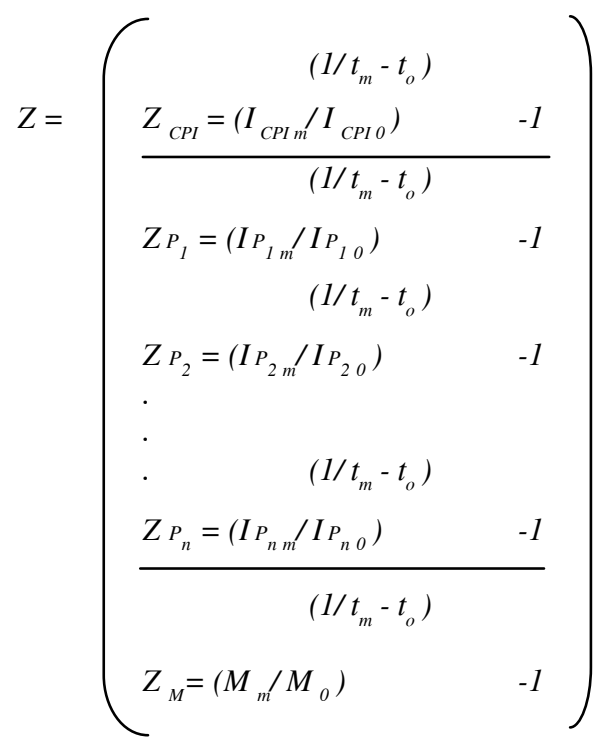

Media $z=\left\{\Sigma\left(I_{P i m} / I_{P i o}\right){ }^{\left(1 / t_{m}-t_{o}\right)}-1 / n=\Sigma\left(Z_{P i}\right) / n\right\}$ where $\mathrm{n}$ is the number of goods and services included in the CPI basket in each of the periods 
2) The median of the distribution of $Z_{P i}$

3) The standard deviation of these average montly variation rates

$S_{Z=}$ standard deviation of the $Z_{P i}$ variation rates
4) The dispersion coefficient

$$
C V_{Z}=S_{Z} / M_{Z}
$$

5) Cumulative averages, medians and variations in the quartiles and deciles of the $Z_{P i}$ distribution

\section{Bibliography}

Barro, R.J. (1995): Inflation and economic growth, Quarterly Bulletin, vol. 35, No. 2, London, Bank of England, May.

Bernanke, B., T. Laubach and others (1999): Inflation Targeting: Lessons from the International Experience, Princeton, Princeton University Press.

Blejer, M.I., A.M. Leone and others (2002): Inflation Targeting in the Context of IMF-Supported Adjustment Programs, IMF Staff Papers, vol. 49, No. 3, Washington, D.C., International Monetary Fund.

Boughton, J.M. (2004): The IMF and the Force of History: Ten Events and Ten Ideas That Have Shaped the Institution, IMF Working Papers, No. 04/75, Washington, D.C., International Monetary Fund.

Bryan, M. and S. Cecchetti (1996): Inflation and the Distribution of Price Changes, NBER Working Paper, No. 5793, Cambridge, Massachusetts, National Bureau of Economic Research, October.

Cukierman, A. (1983): Relative Price Stability and Inflation: A Survey and Further Results, Carnegie-Rochester Conference Series on Public Policy, Amsterdam, NorthHolland.

ECLAC (Economic Commission for Latin America and the Caribbean) (1985): Change and crisis: Latin America and the Caribbean 1950-1985, Crisis and Development: the Present Situation and Future Prospects of Latin America and the Caribbean, vol. 1, (LC/L.332 (Sem.22/3)), Santiago, Chile.

Fisher, S. (1996): Central banking: the challenges ahead, maintaining price stability, Finance and Development, vol. 33, No. 4, Washington, D.C., International Monetary Fund/World Bank, December. Available in www.worldbank.org/fandd/english/1296/articles/ 0101296.htm
Frenkel, R. (1995): Las políticas antiinflacionarias en América Latina, Buenos Aires, Centro de Estudios de Estado y Sociedad (CEDES).

Goodhart, C.A.E. (2000): What Weight Should be Given to Asset Prices in the Measurement of Inflation?, Third Annual Conference "Measuring Inflation for Monetary Policy Purposes", Amsterdam, De Nederlandche Bank.

IPEA (Institute of Applied Economic Research) (2005): Boletín de conjuntura, No. 69, Rio de Janeiro, June.

Laidler, D. (2003): The Price Level, Relative Prices and Economic Stability: Aspects of the Interwar Debate, BIS Working Papers, No. 136, Basel, Bank for International Settlements, September.

Pinto, A. (1968): Raíces estructurales de la inflación en América Latina, Estabilidad monetaria y desarrollo económico, Mexico City, Arte y Cultura.

Roger, S. (2000): Relative Prices, Inflation and Core Inflation, IMF Working papers, No. 00/58, Washington, D.C., International Monetary Fund, March.

Sáinz, P. and A.F. Calcagno (1992): In search of another form of development, CEPAL Review, No. 48, LC/G.1748-P, Santiago, Chile, December.

(1999): La economía brasileña ante el Plan Real y su crisis, Temas de coyuntura series, No. 4, LC/L.1232-P, Santiago, Chile, Economic Commission for Latin America and the Caribbean (ECLAC), July. United Nations publication, Sales No. S.99.II.G.13.

The Economist (2005): From t-shirts to t-bonds, London, 28 July.

Vining, D.R. and Th. Elwertowski (1976): The relationship between relative prices and the general price level, The American Economic Review, vol. 66, No. 4, Nashville, Tennessee, American Economic Association, September. 